OPEN ACCESS

Edited by:

Fredrik Rosqvist

Uppsala University, Sweden

Reviewed by:

David Iggman,

Landstinget Dalarna, Sweden

Domenico Tricò,

University of Pisa, Italy

*Correspondence:

Daniel J. Cuthbertson

dan.cuthbertson@liverpool.ac.uk

Specialty section:

This article was submitted to

Nutrition and Metabolism,

a section of the journal

Frontiers in Nutrition

Received: 11 December 2020

Accepted: 27 January 2021

Published: 16 February 2021

Citation:

Hydes T, Alam $U$ and Cuthbertson DJ (2021) The Impact of Macronutrient Intake on Non-alcoholic Fatty Liver Disease (NAFLD): Too Much Fat, Too Much Carbohydrate, or Just Too Many Calories? Front. Nutr. 8:640557. doi: 10.3389/fnut.2021.640557

\section{The Impact of Macronutrient Intake on Non-alcoholic Fatty Liver Disease (NAFLD): Too Much Fat, Too Much Carbohydrate, or Just Too Many Calories?}

\author{
Theresa Hydes ${ }^{1,2}$, Uazman Alam ${ }^{1,2}$ and Daniel J. Cuthbertson ${ }^{1,2 *}$ \\ ${ }^{1}$ Department of Metabolic and Cardiovascular Medicine, Institute of Life Course and Medical Sciences, University of \\ Liverpool, Liverpool, United Kingdom, ${ }^{2}$ Liverpool University Hospitals NHS Foundation Trust, Liverpool, United Kingdom
}

Non-alcoholic fatty liver disease (NAFLD) is a growing epidemic, in parallel with the obesity crisis, rapidly becoming one of the commonest causes of chronic liver disease worldwide. Diet and physical activity are important determinants of liver fat accumulation related to insulin resistance, dysfunctional adipose tissue, and secondary impaired lipid storage and/or increased lipolysis. While it is evident that a hypercaloric diet (an overconsumption of calories) promotes liver fat accumulation, it is also clear that the macronutrient composition can modulate this risk. A number of other baseline factors modify the overfeeding response, which may be genetic or environmental. Although it is difficult to disentangle the effects of excess calories vs. specifically the individual effects of excessive carbohydrates and/or fats, isocaloric, and hypercaloric dietary intervention studies have been implemented to provide insight into the effects of different macronutrients, sub-types and their relative balance, on the regulation of liver fat. What has emerged is that different types of fat and carbohydrates differentially influence liver fat accumulation, even when diets are isocaloric. Furthermore, distinct molecular and metabolic pathways mediate the effects of carbohydrates and fat intake on hepatic steatosis. Fat accumulation appears to act through impairments in lipid storage and/or increased lipolysis, whereas carbohydrate consumption has been shown to promote liver fat accumulation through de novo lipogenesis. Effects differ dependent upon carbohydrate and fat type. Saturated fat and fructose induce the greatest increase in intrahepatic triglycerides (IHTG), insulin resistance, and harmful ceramides compared with unsaturated fats, which have been found to be protective. Decreased intake of saturated fats and avoidance of added sugars are therefore the two most important dietary interventions that can lead to a reduction in IHTG and potentially the associated risk of developing type 2 diabetes. A healthy and balanced diet and regular physical activity must remain the cornerstones of effective lifestyle intervention to prevent the development and progression of NAFLD. Considering the sub-type of each macronutrient, in addition to the quantity, are critical determinants of liver health.

Keywords: non-alcoholic fatty liver disease, carbohydrate, saturated fat, over-feeding, de novo lipogenesis (DNL), adipose tissue expandability, fructose, randomized study 


\section{INTRODUCTION}

There have been many feeding/overfeeding studies performed and published that have elegantly outlined the whole body, multi-organ, and molecular/cellular effects of human overfeeding in an effort to recapitulate the chronic nutrient excess that has characterized the current obesity epidemic, providing mechanistic insight into the biological adaptations that occur with weight gain and development of overweight/obesity. These studies have been undertaken in individuals with an array of differing baseline characteristics [age, body mass index (BMI), insulin sensitivity, metabolic health status, obesity prone/resistant genotype etc.] and have adopted different study designs (parallel arm vs. cross-over), of progressively longer duration (from hours to many months). They have imposed different feeding regimes (caloric quantity vs. different macronutrient compositions [fat vs. carbohydrate etc.]) with the aim of weight maintenance, or of inducing identical absolute or relative weight gain for a fixed time period, some with concomitant changes in physical activity. The focus of these studies has been hugely varied examining the effects on energy balance, on structure and function of specific organs/tissues (adipose tissue, skeletal muscle, liver, brain, pancreas) and on inter-organ cross talk. Various experimental techniques have been employed including assessment of behavioral responses, dynamic metabolic assessment using an array of indirect calorimetry, metabolic chambers, stable isotopes, hyperinsulinaemic-euglycaemic clamps, and meal tolerance tests, imaging with dual energy $\mathrm{x}$-ray absorptiometry (DEXA)/computerized tomography (CT)/magnetic resonance imaging (MRI) to assess changes in regional and total body composition and tissue (adipose tissue/skeletal muscle) biopsies, often used in parallel to provide complementary data and an integrated perspective. More than 300 such studies have been recently comprehensively reviewed in an extensive systematic review of human overfeeding studies (1).

The purpose of this narrative review is to examine the impact of different dietary regimes, frequently with contrasting macronutrient composition, seeking evidence from recent overfeeding studies that have provided valuable mechanistic insight, to examine factors that drive liver fat accumulation and damage, in an attempt to better understand the pathophysiology of non-alcoholic fatty liver disease (NAFLD). It is not intended to provide exhaustive epidemiological data nor review evidence for specific dietary manipulations or physical activity interventions, despite a clear acknowledgment that cardiorespiratory fitness, regular physical activity, and 5-10\% weight reduction remain key cornerstones of ideal management $(2,3)$.

\section{EPIDEMIOLOGY OF NAFLD}

NAFLD is a major public health problem ranging from hepatic steatosis, an excessive accumulation of intrahepatic triglycerides (IHTG) affecting approximately a quarter of adults, to nonalcoholic steatohepatitis (NASH), in which hepatic inflammation and cellular injury occurs leading eventually to fibrosis, the key driver of cirrhosis $(4,5)$. Hepatocellular carcinoma (HCC) has an annual incidence of around 10 per 1,000 person years in NAFLD cirrhosis, although NASH has been found to be associated with an elevated risk of HCC even in the absence of cirrhosis (6).

Hepatic fat content is an important driver of the metabolic syndrome, partly related to increased hepatic insulin resistance (7), and therefore is associated with obesity and related metabolic disorders, namely insulin resistance, prediabetes, type 2 diabetes (T2D), and cardiovascular disease $(8,9)$. NAFLD is also associated with a number of other systemic complications including chronic kidney disease, and a variety of malignancies, hepatic, and extra-hepatic (10).

NAFLD was not recognized as a clinical entity until 1980 (11), but has been exponentially increasing in prevalence in all populations across all ages (including pediatric and adolescent populations), socioeconomic groups (disproportionately afflicting the more socioeconomically deprived), and in developing countries where Western diets have become more common place (4).

Both over nutrition and sedentary lifestyle has been demonstrated to be associated with the NAFLD spectrum in both animals and humans (12-14), and thus improved nutrition and increased physical activity serves as a major therapeutic route to prevention and treatment. Dietary composition has an important impact on the pathogenesis of NAFLD and different dietary macronutrient composition influences the pathways, mediators, and magnitude of weight gain-induced changes in IHTG content. Excessive consumption of fat and sugars are the root causes of human metabolic disease with saturated fat and fructose being the main dietary components that stimulate hepatic lipid accumulation and progression to NASH, whereas unsaturated fat, choline, antioxidants, and high protein diets appear to play a protective role. The European Association for the Study of the Liver support "exclusion of processed food, and food and beverages high in added fructose," as well as a macronutrient composition in line with a Mediterranean diet however, these recommendations are only supported by evidence graded "moderate" in quality (2), and other organizations including the American Association for the Study of Liver Disease make no dietary recommendations for individuals with NAFLD (15). The evidence around these dietary components will be discussed in more detail.

\section{NUTRIENT-INDUCED DRIVERS OF LIVER FAT ACCUMULATION \\ Distribution of Excess Energy Amongst Tissues}

Although excessive energy intake is a key driver of NAFLD, relatively few human studies have investigated the influence of (isocaloric) dietary composition on biological processes occurring in the liver and ectopic fat accumulation to understand the metabolic consequences of contrasting dietary fats and carbohydrates. Important inter-organ crosstalk occurs between the gut (small intestine), liver, and other peripheral organs including adipose tissue and skeletal muscle (Figure 1). 


\section{Ectopic fat deposition and multi-organ implications of overfeeding}

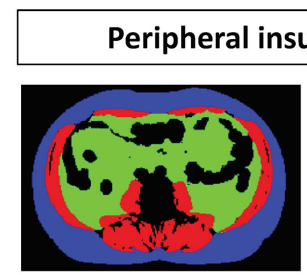

Visceral fat (green) Skeletal muscle

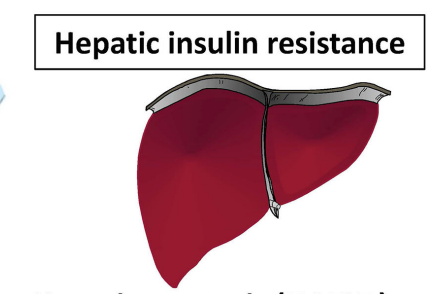

Hepatic steatosis (NAFLD)

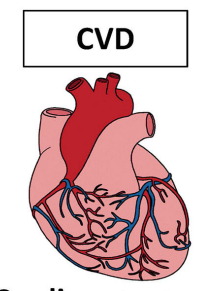

Cardiac steatosis

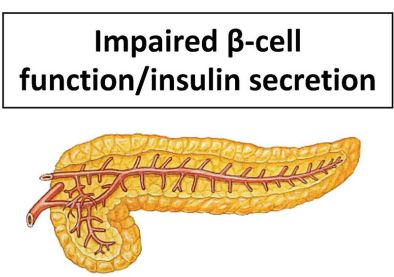

Pancreatic steatosis >subcutaneous fat (blue)

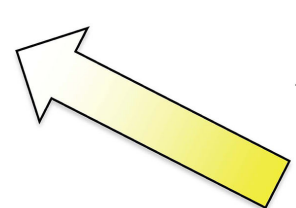

M2 macrophage

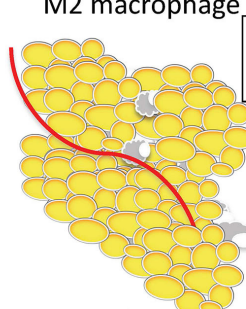

Lean adipose tissue Anti-inflammatory milieu

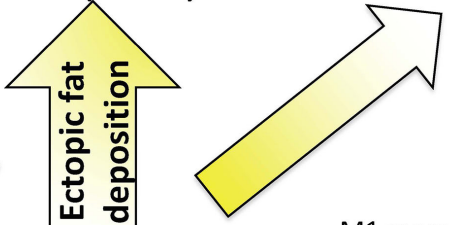

M1 macrophage

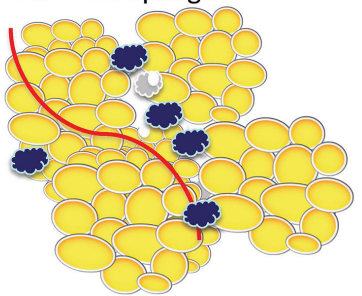

Obese adipose tissue Pro-inflammatory milieu

FIGURE 1 | The "adipose tissue expandability" hypothesis leading to deposition of ectopic fat into the liver and other organs.

\section{Biological Mechanisms to Explain Metabolic Phenotypes}

Results from transgenic animal studies, in which subcutaneous adipose tissue (SAT) may undergo massive expansion, demonstrate SAT to be metabolically inert, providing a safe haven for toxic lipids, with consequently reduced ectopic fat (e.g., liver/pancreas/visceral fat) and preservation of insulin sensitivity (16). In contrast, a lesser capacity for SAT expansion is associated with greater ectopic fat deposition, development of systemic insulin resistance, metabolic syndrome, and atherosclerosis (17).

\section{The Adipose Tissue Expandability Hypothesis}

The adipose tissue expandability hypothesis has been proposed suggesting that SAT expansion occurs during positive energy balance, but that once the SAT capacity to store energy has been exceeded and maximal SAT expansion has occurred, there is widespread organ-specific ectopic fat deposition (steatosis) in visceral adipose tissue (VAT), liver, pancreas, cardiac, and skeletal muscle (Figure 1) (18). The functional consequences on the organs is lipotoxicity causing hepatic insulin resistance and impaired beta cell function (a sequence of events explained by the twin cycle hypothesis) in addition to myocardial dysfunction (19). The absolute storage capacity of SAT has a huge inter-individual variation, unique to the individual as proposed by the personal fat threshold (18).

\section{Regulation of Liver Fat Content}

The quantity of IHTG is dependent upon the relative balance of lipid inflow and lipid removal (Figure 2). Lipid influx maybe derived from a variety of metabolic sources including dietary intake/intestinal (15\%), adipose tissue lipolysis (increased flux of non-esterified fatty acids, NEFAs) (60-80\%) and hepatic de novo lipogenesis (DNL) (endogenous synthesis of saturated fatty acids (SFAs) including palmitate from glucose, fructose, or both) (5\%). All contribute to liver fat accumulation in distinct proportions. Lipid removal is mediated by both mitochondrial fatty acid $\beta$-oxidation and re-esterification to triglyceride (TG) which is either stored or exported into the systemic circulation as very low-density lipoprotein (VLDL). Liver fat accumulates differentially according to the fatty acid composition and/or carbohydrate content/type but significantly appears to do so through different molecular/cellular pathways. Increasing levels of IHTG can drive insulin resistance which in turn may increase the rate of DNL (20). Insulin-resistant adipose tissue also leads to enhanced lipolysis.

\section{Molecular Pathways in the Liver}

Different dietary patterns or certain nutrients may directly promote NAFLD by promoting hepatic TG accumulation and inhibiting antioxidant activity, and indirectly by affecting insulin sensitivity and post-prandial TG metabolism. In general, these include simple sugars (fructose), SFAs, trans-fatty acids and animal protein. Nutrients may do so by acting on a variety of 


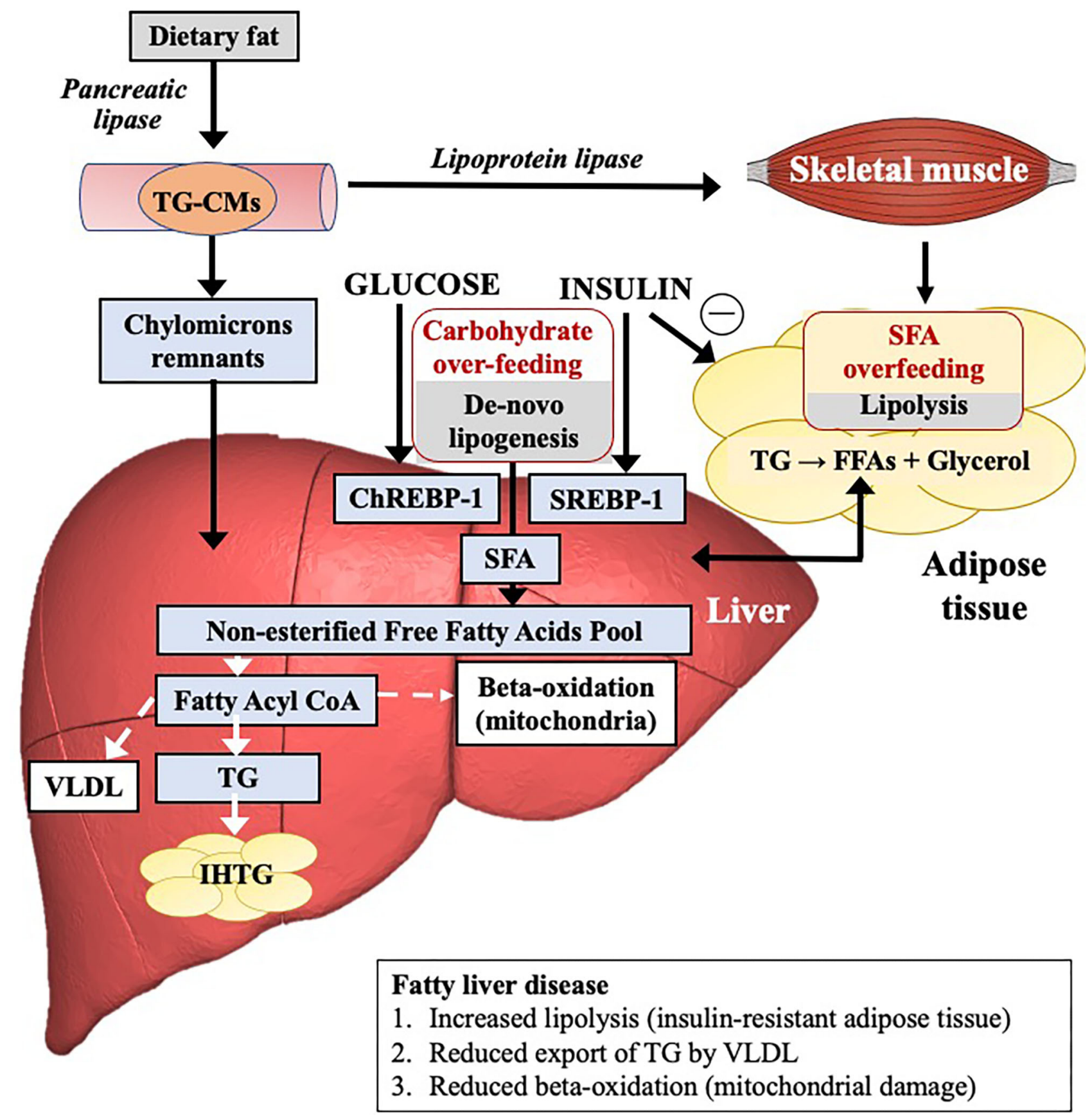

FIGURE 2 | The mechanistic pathways leading to the accumulation of intrahepatic triglycerides and influence of fat or carbohydrate overfeeding on these pathways.

hepatic nuclear receptors to regulate these processes including the liver $\mathrm{X}$ receptor (hepatic fatty acid synthesis), the farnesoid $\mathrm{X}$ receptor (VLDL assembly), and the peroxisome proliferatoractivated receptors (PPARs: PPAR- $\alpha$, fatty acidv oxidation; PPAR- $\gamma$, anti-inflammatory function; PPAR- $\delta$ suppresses hepatic lipogenesis, and reduces the hepatic expression of proinflammatory genes), as well as cytoplasmic transcription factors such as sterol regulatory element-binding protein (SREBP)-1.
Contribution of Glucose-Dependent Insulinotropic Polypeptide (GIP) Release and the Gut Microbiome to NAFLD

The gut may modulate fat accretion through different patterns of secretion of intestinal GIP (being most potently stimulated by saturated fat) (21). Additionally, the gut plays a role in NAFLD progression with alterations in gut permeability, the microbiome, and associated endotoxemia contributing to the risk 
of NAFLD and NASH. While the overall community structure of the gut microbiota appears to remain resilient to shortterm overfeeding with both fats and simple sugars, carriage of the anaerobe Bilophila has been identified as a potential risk factor for diet-induced liver steatosis (22). There is also evidence that certain patterns of microbiota (e.g., in T2D) may produce metabolites, specifically histidine-derived imidazole propionate, that can induce insulin resistance by impairing signal transduction through the insulin signaling pathway. These data provide an important mechanistic link between altered patterns of gut microbiota and whole-body metabolism (23).

\section{Timing and Pattern of Ingestion}

Although beyond the scope of this review, the timing of macronutrient intake relative to sleep/wake cycle and the pattern of ingestion is also relevant $(24,25)$.

\section{MACRONUTRIENT COMPOSITION}

Before discussing the effects of overconsumption, it is useful to summarize the different types and subtypes of macronutrients (Figure 3).

\section{Carbohydrates}

Carbohydrates are the sugars, starches and fibers found in fruits, grains, vegetables, and dairy products. They can be divided into whole vs. refined carbohydrates. Whole carbohydrates include fruits, leafy greens, starchy vegetables, beans, peas, lentils, and whole grains. These carbohydrates are high in fiber, vitamins, minerals, antioxidants, and water and are minimally processed. Refined carbohydrates are processed to remove the protein and fat-rich germ and fiber-rich bran, leaving only the starchy endosperm. They are therefore low in fiber and micronutrients. Examples include white rice, white bread, pastries, sugary cereals, sugary drinks, and sweets.

\section{Fructose}

Fructose is a monosaccharide commonly found in fruits, vegetables and honey (5-10\% fructose), but due to its sweetness is also a major component in the two most commonly used sweeteners, sucrose, and high fructose corn syrup (HFCS, a mixture of fructose and glucose monosaccharides). HFCS is found in soft drinks and pre-packaged foods.

\section{Glucose}

Glucose is present in all major carbohydrates, such as starch and table sugar. Glucose is metabolized primarily by glucokinase or hexokinase. It is found in its free state in fruits and plants and is a component of fruit juices, sugar-sweetened beverages (SSB), and processed foods.

\section{Sucrose}

Sucrose is a disaccharide composed of glucose and fructose. It occurs naturally in sugarcane, sugar beets, dates, and honey. It is often the sole component of table sugar and is also found in high quantities in maple syrup and chocolate.

\section{Lactose}

Lactose is composed of glucose and galactose and is found predominantly in milk and other dairy products.

\section{Fats}

Fats can be divided into three groups: trans-fatty acids, saturated fat and unsaturated fat.

\section{Trans-Fatty Acids (TFAs)}

Trans-fatty acids (TFAs) are found in fast and fried foods, partially hydrogenated vegetable oil, cakes and pastries, and can increase serum cholesterol. The availability of industrial TFA from partially hydrogenated vegetable oils is being increasingly limited and is forbidden in some countries. Small amounts of TFAs are also found in fats from ruminant animals.

\section{Saturated Fatty Acids}

Saturated fatty acids generally originate from animal sources including fatty meat, butter, full fat dairy products, and tropical oils, including palm oil and coconut oil. Excessive consumption of SFAs, common in western diets, can cause insulin resistance and raise serum low-density lipoprotein (LDL) cholesterol levels.

\section{Unsaturated Fatty Acids}

Unsaturated fatty acids are either poly or monounsaturated. Sources of monounsaturated fats (MUFAs) include olive oil, rapeseed oil, soy, avocados, and certain nuts. Monounsaturated fats reduce levels of LDL cholesterol while maintaining high concentrations of high-density lipoprotein (HDL) cholesterol. Polyunsaturated fats (PUFAs) can be divided into the omega3 (n-3) and omega-6 (n-6) families. Omega-6 fats are found in vegetable oils (corn, sunflower oil), seeds (rapeseed, flaxseed oil), soybean oil, and nuts. Omega- 3 fats are sourced from fish oils and algae, as well as rapeseed oil, soy, walnuts and flaxseed oil. PUFAs have been shown to improve LDL cholesterol levels to an even greater extent than MUFAs, and importantly may also improve insulin sensitivity (26).

\section{OBSERVATIONAL DATA OF DIETARY PATTERNS}

Epidemiological data on dietary risk factors for NAFLD from population-based studies are scarce. Most human studies are observational and retrospective, allowing limited inference about causal associations. From those studies that are available we have seen clear positive associations of NAFLD with intake of red and processed red meat, poultry and cholesterol and negative associations with dietary fiber intake $(27,28)$. Lower hepatic PUFA levels were also associated with NAFLD in a cross-sectional study (29).

\section{EFFECT OF EXCESS ENERGY INTAKE AND SPECIFIC MACRONUTRIENTS ON LIVER FAT}

Experimental overfeeding can be implemented using excess energy from any form of hypercaloric diet. The diet may be 
A

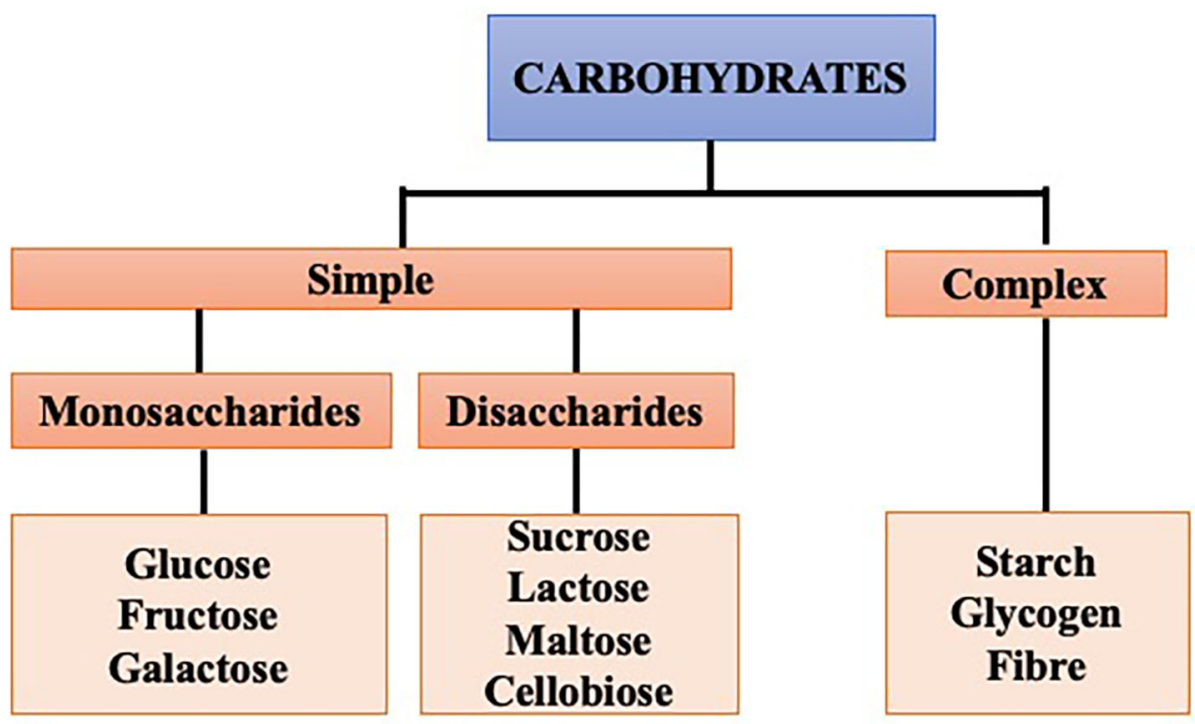

B

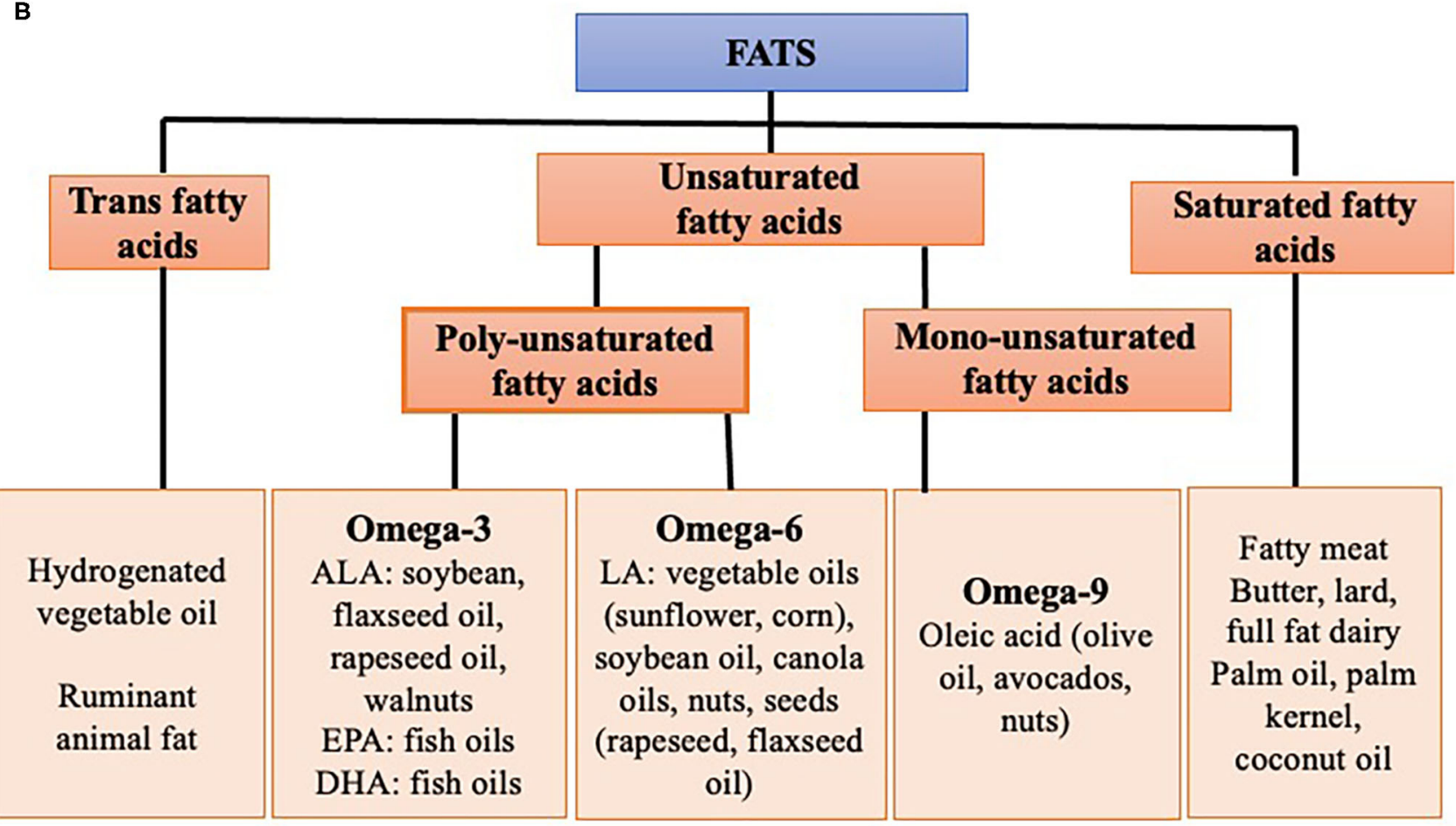

FIGURE 3 | Subtypes of macronutrients (A) carbohydrates, (B) fat.

balanced or unbalanced according to the relative amounts of fat, carbohydrate or protein, or may involve consumption of a particular type of fat or carbohydrate. The mechanisms by which specific macronutrients in excess cause a change in liver fat (and indeed other ectopic fat depots) are of interest. The methodologies range from more simple study designs to complex multi-modality assessments concomitantly examining changes in functional adipose tissue characteristics, body composition (with
DEXA and/or MRI $/{ }^{1} \mathrm{H}$-magnestic resonance spectroscopy, MRS) and the metabolic consequences (using oral glucose tolerance test or euglycaemic clamps) (30). Key overfeeding studies that have provided an insight into the impact of short- and longerterm excess carbohydrate or fat ingestion on liver fat content are shown in Tables 1-3; and their effect on adipose tissue expansion, insulin sensitivity, and other metabolic profiles are shown in Supplementary Tables 1-3. 
Some key findings of these studies have recently been borne out in a systematic review and meta-analysis of 26 randomized controlled trials assessing the effects of dietary macronutrient composition on liver fat content (51). In order to do this only isocaloric diets were considered; a quarter were over-feeding studies, i.e., the dietary intervention was provided as an energy surplus, and the rest involved isoenergetic diets or restricted energy intake compared to baseline. As expected, unsaturated fats were found to reduce liver fat content compared to SFAs (standardized mean difference (SMD) -0.80 [95\% CI -1.09 to -0.51). Replacement of carbohydrate with protein also led to a moderate reduction in liver fat overall although only three studies were included (SMD -0.33 [95\% CI -0.54 to -0.12$]$ ). Finally, a comparison of high-carbohydrate/low-fat vs. lowcarbohydrate/high-fat diets revealed significant heterogeneity between studies; three studies concluded the high fat diet resulted in lower levels of steatosis, two studies concluded the opposite and seven studies found no difference (overall pooled effect 0.01 [95\% CI -0.37 to 0.36$])$.

\section{The Impact of Carbohydrate Ingestion and Excess Carbohydrate Consumption on the Liver}

A number of studies have examined the relative roles of glucose and fructose in the adverse metabolic alterations associated with excessive sugar consumption. Results from clinical studies indicate that reductions in sugary beverages and total fructose intake, especially from added sugars, have a significant benefit in reducing hepatic fat accumulation (52). This is borne out by the findings from a number of metaanalyses suggesting the consumption of SSBs is related to the risk of metabolic syndrome; increased TG levels, stimulated DNL and increased visceral fat $(53,54)$. Fructose may drive NAFLD through multiple mechanisms: (i) hepatic: fructose increases the transcription factor carbohydrate-responsive element-binding protein (ChREBP-1), a master regulator of DNL, while it also impairs hepatic $\beta$-fatty acid oxidation, (ii) gut-mediated: fructose is principally metabolized by fructokinase which is highly expressed in the small intestine. Metabolism of fructose in the intestine results in disruption of the tight junctions responsible for increased gut permeability, leading to bacterial and bacterial endotoxin translocation (55).

Overfeeding with carbohydrates (simple sugars) has been shown to lead to significant increases in liver fat content in a majority of studies as determined by ${ }^{1} \mathrm{H}$-MRS (Table 1) $(25,31-$ $35,38,47,48,50)$. Significant changes in liver fat deposition can occur within a week of overfeeding $(31-33,47,48)$ and in some studies this has been shown to be independent of total body weight gain $(33,38,47,48,50)$. Sevastianova et al. assigned 16 subjects with a mean BMI of 30.6 to a 3 week high carbohydrate diet and reported a 10 -fold greater relative change in liver fat (27\%) compared to body weight (2\%) (35). A randomized study comparing 6 months of overfeeding with sucrose-sweetened cola or milk revealed that individuals consuming the cola had significantly greater liver fat content at the end of the intervention despite energy consumption between the groups being comparable (38).

Various methodologies have demonstrated an increase in hepatic production of the saturated fat palmitate following carbohydrate overfeeding, indicating a link between excess dietary sugar and the accumulation of liver fat through DNL as opposed to lipolysis (Figure 2, Table 1) (31, 33, 35, 50). Furthermore, increases in liver fat following a high carbohydrate diet positively correlate with DNL (35). This suggests that the liver accumulates fat during carbohydrate overfeeding and supports a role for DNL in the pathogenesis of NAFLD.

While the evidence of the relationship between excess intake of mono- and disaccharides with hepatic steatosis is now wellestablished, studies vary in their findings of whether hepatic transaminases increase following dietary intervention, suggesting there may be an interplay with other risk factors required to bring about liver inflammation (Table $\mathbf{1}$ ).

In terms of other metabolic parameters, carbohydrate overfeeding consistently results in raised levels of TG and VLDLTG, likely a reflection of an increase in DNL, whereas its impact on the rest of the lipid profile is minimal in the majority of studies (Supplementary Table 1). While SAT volumes are generally increased $(25,35,38)$, the influence of carbohydrate overfeeding on VAT is particularly pronounced (38). Glycaemic parameters, including fasting plasma glucose and insulin levels, in addition to markers of insulin sensitivity vary excessively between studies with approximately half demonstrating no change following dietary intervention (31-38).

Although some studies have suggested that fructose has more steatogenic potential than glucose, in that it has been demonstrated to lead to enhanced DNL, greater volumes of VAT, altered lipid metabolism and lower levels of insulin sensitivity (56), data from a double blind parallel randomized control trial suggests that the effects on liver enzymes and triacylglcerol (TAG) concentrations are similar (34). Johnston et al. assigned 32 overweight individuals to receive either a high fructose or high glucose hypercaloric diet for 2 weeks with a 6 week washout period (34). The two groups experienced similar increases in weight, and concentrations of TAG in both the liver and serum, in addition to comparable changes in alanine transaminase and aspartate transaminase. No such changes occurred where an isocaloric diet was followed for either group.

The glycaemic index (GI) of carbohydrates does appear to be an important modulator as shown from a crossover trial in which over 80 healthy volunteers consumed either a high or a low GI diet for 7 days (57). The authors reported an increase in the liver fat fraction (and higher hepatic glycogen concentrations) with a high GI diet, whereas liver fat decreased following a low GI $\operatorname{diet}(57)$.

Given the association between fructose and NAFLD described above, there may be some confusion regarding fruit which naturally contains fructose. Fruit is part of the Mediterranean diet which is recommended for individuals with NAFLD (2). Most fruits have a relatively low GI depending on factors including ripeness. The quantities of fructose found in fruit are considerably lower than those found in SSBs; for example one pear contains about $12 \mathrm{~g}$ fructose, compared to $37 \mathrm{~g}$ in a can of 
TABLE 1 | Summary of studies examining the impact of carbohydrate over-feeding on liver fat.

\begin{tabular}{|c|c|c|c|c|c|c|c|c|}
\hline References & Participants & Design & Intervention & Duration & Body weight (kg) & Liver fat ( $\left.{ }^{1} \mathrm{H}-\mathrm{MRS}, \%\right)$ & ALT, AST (U/L) & Markers of DNL \\
\hline \multicolumn{9}{|c|}{ Shorter duration ( $\leq 1$ week) } \\
\hline Lê et al. (31) & $\begin{array}{l}\text { Off-spring of } \\
\text { people with T2D } \\
\text { (OffT2D) }(n=16) \\
\text { Controls }(n=8)\end{array}$ & $\begin{array}{l}\text { Randomized } \\
\text { Cross-over }\end{array}$ & $\begin{array}{l}\text { Isocaloric diet }+3.5 \\
\text { g/kg/FFM fructose }+35 \% \\
\text { EE (HFrD) }\end{array}$ & $\begin{array}{l}7 \text { days } \\
4-5 \text { week washout }\end{array}$ & $\begin{array}{l}\text { Controls }+0.6 \\
\text { OffT } 2 \mathrm{D}+1.0 \\
\text { Diet, } p<0.05 \\
\text { Groups, } p=\mathrm{ns}\end{array}$ & $\begin{array}{l}\text { OftT2D }+79 \% \\
\text { Controls }+76 \% \\
\text { Groups, } p=\mathrm{ns}\end{array}$ & $\begin{array}{l}\text { ALT: Controls } \\
16.9 \pm 1.2 \rightarrow \\
24.9 \pm 4.2 ; \\
\text { OffT2D } 16.4 \pm 1.0 \\
\rightarrow 29.3 \pm 4.2 \\
\text { Groups, } p=\mathrm{ns}\end{array}$ & $\begin{array}{l}\text { 18:2n26: } 16: 0 \text { in serum } \\
\text { VLDL TAG: } \\
\text { Controls } 0.36 \rightarrow 0.31 \\
(p<0.001) \\
\text { Off2D 0.35 } \rightarrow 0.27 \\
(p<0.001) \\
\text { Groups, } p=n s\end{array}$ \\
\hline $\begin{array}{l}\text { Ngo Sock et al. } \\
\text { (32) }\end{array}$ & $\begin{array}{l}\text { Non-diabetic men } \\
(n=11)\end{array}$ & $\begin{array}{l}\text { Randomized } \\
\text { Cross-over }\end{array}$ & $\begin{array}{l}\text { 1. WM+3.5 g/kg/FFM } \\
\text { fructose (HFrD) } \\
\text { 2. WM+3.5 g/kg/FFM } \\
\text { glucose (HGlcD) HFrD/HG } \\
+35 \% \mathrm{EE}\end{array}$ & $\begin{array}{l}7 \text { days } \\
2-3 \text { week washout } \\
\text { GlcD }\end{array}$ & $\begin{array}{l}\text { HFrD }+0.6 \\
\text { HGlcD }+1.0 \\
\text { t HFrD vs. WM, } p< \\
0.01 \\
\text { HGlcD vs. WM, } p \\
<0.05\end{array}$ & $\begin{array}{l}\text { HFrD }+52 \pm 13 \%, H G l c D+58 \pm 23 \% \\
\text { HFrD vs. WM, } p<0.05 \\
\text { HGlcD vs. WM, } p=n s \\
\text { HFrD vs. HGIcD, } p=n s\end{array}$ & $\begin{array}{l}\text { ALT, AST: } p=\mathrm{ns} \\
\text { vs. WM diet }\end{array}$ & \\
\hline $\begin{array}{l}\text { Theytaz et al. } \\
\text { (33) }\end{array}$ & $\begin{array}{l}\text { Non-diabetic men } \\
(n=9)\end{array}$ & $\begin{array}{l}\text { Randomized } \\
\text { Cross-over }\end{array}$ & $\begin{array}{l}\text { 1. } \mathrm{HFrD}(3 \mathrm{~g} / \mathrm{kg})+\text { placebo } \\
(+36 \% \mathrm{EE}) \\
\text { 2. } \mathrm{HFrD}(3 \mathrm{~g} / \mathrm{kg})+\mathrm{EAA} \\
(\mathrm{HFrAA})(+38 \% \mathrm{EE})\end{array}$ & $\begin{array}{l}6 \text { days } \\
4-10 \\
\text { week washout }\end{array}$ & $p=n s$ with diet & $\begin{array}{l}\text { WM }+1.27 \pm 0.31 \\
\text { HFrD }+2.74 \pm 0.55(p<0.05 \text { vs. WM) } \\
\text { HFrD vs. HFrAA, } p<0.05\end{array}$ & & $\begin{array}{l}{ }^{13} \mathrm{C} \text { palmitate } \\
\text { production } \\
\text { (nmol/540 min): } \\
\text { WM } 1.0 \pm 3.9 \\
\text { HFD } 182.2 \pm 52(p< \\
0.05 \text { vs. WM) }\end{array}$ \\
\hline \multicolumn{9}{|c|}{ Longer duration (> 1 week) } \\
\hline $\begin{array}{l}\text { Johnston et al. } \\
\text { (34) }\end{array}$ & $\begin{array}{l}\text { Non-diabetic men } \\
(n=32)\end{array}$ & $\begin{array}{l}\text { Randomized } \\
\text { Cross-over } \\
\text { Double blind }\end{array}$ & $\begin{array}{l}\text { 1. Isocaloric HGID/HFrD } \\
\text { 2. Hypercaloric (HcID) } \\
\text { (+25\% EE) HGID/HFrD }\end{array}$ & $\begin{array}{l}2 \text { weeks } \\
6 \text { week washout }\end{array}$ & $\begin{array}{l}\text { Results for HcID } \\
\text { HFrD }+1.0 \pm 1.4 \\
(p<0.05) \\
\text { HGID }+0.6 \pm 1.0 \\
(p<0.05) \\
\text { HFrD vs. HGID, } p \\
=n s\end{array}$ & $\begin{array}{l}\text { Results for HcID } \\
\text { aHFrD }+1.70 \pm 2.6(p<0.05) \\
\text { HGID }+2.05 \pm 2.9(p<0.05) \\
\text { HFrD vs. HGID, } p=n s\end{array}$ & $\begin{array}{l}A L T, A S T: \\
p=n s \text { for HCID } \\
p=n s \text { for HFrD } \\
\text { vs. HGID }\end{array}$ & \\
\hline $\begin{array}{l}\text { Sevastianova } \\
\text { et al. (35) }\end{array}$ & $\begin{array}{l}\text { Non-diabetics } \\
\text { genotyped for } \\
\text { PNPLA3. }(n=16) \text {. } \\
\text { Mean BMI } 30.6 \\
\mathrm{~kg} / \mathrm{m}^{2}\end{array}$ & One group & $\begin{array}{l}\text { Hypercaloric diet (>1,000 } \\
\text { kcal/day simple sugars) }\end{array}$ & 3 weeks & $\begin{array}{l}+1.8 \pm 0.3(p< \\
0.0001)\end{array}$ & $+27 \%(9.2 \pm 1.9 \rightarrow 11.7 \pm 1.9), p<0.05$ & $\begin{array}{l}\text { ALT: }+28 \% \\
(50 \pm 11 \rightarrow \\
64 \pm 16), p<0.05 \\
\text { AST: }+19 \% \\
(36 \pm 4 \rightarrow \\
43 \pm 6), p<0.05\end{array}$ & $\begin{array}{l}\text { 16:0: 18:2n26 in serum } \\
\text { VLDL TG: }+52 \% \\
(2.1 \pm 0.3 \rightarrow \\
3.2 \pm 0.5), p<0.05 \\
\text { Positively correlated } \\
\text { with liver fat during } \\
\text { overfeeding }(p<0.05)\end{array}$ \\
\hline Lê et al. (36) & $\begin{array}{l}\text { Non-diabetic men } \\
(n=7)\end{array}$ & One group & $\begin{array}{l}\text { Isoenergetic diet }+1.5 \\
\mathrm{~g} / \mathrm{kg} / \mathrm{d} \text { fruct }(+18 \% \mathrm{EE})\end{array}$ & 4 weeks & $p=\mathrm{ns}$ with diet & $p=\mathrm{ns}$ & & \\
\hline
\end{tabular}




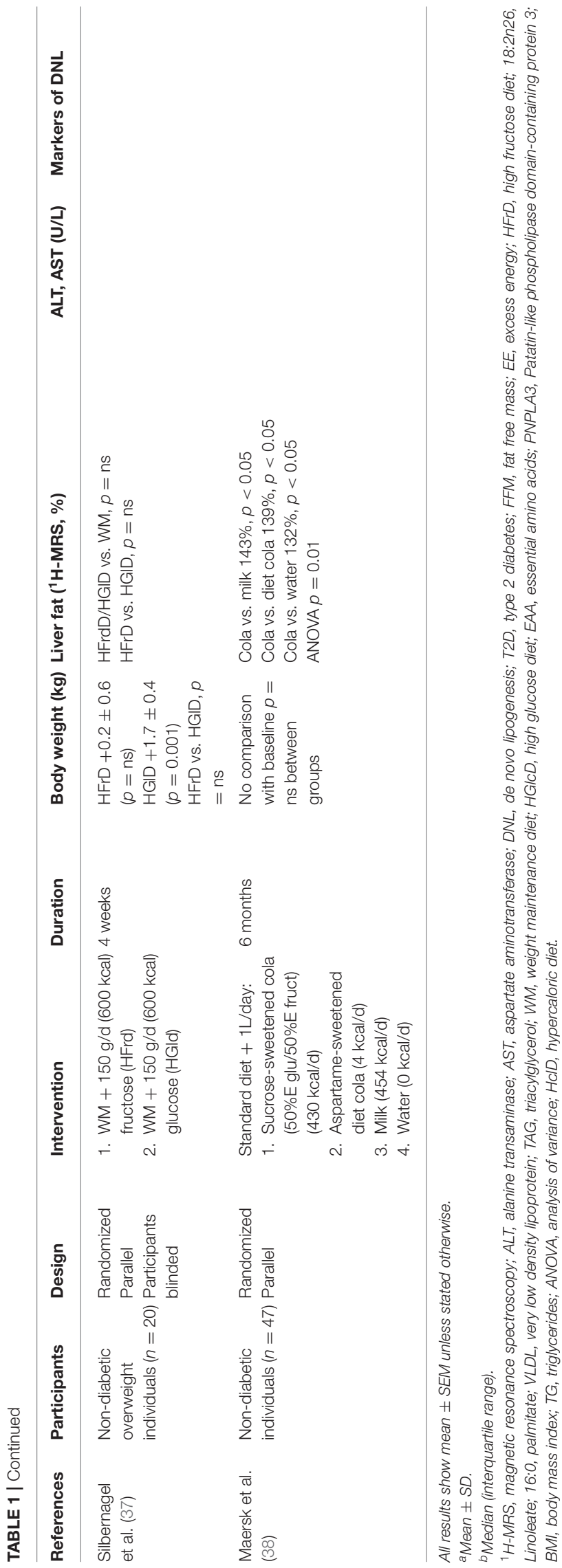

cola and $\sim 30 \mathrm{~g}$ in a $450 \mathrm{ml}$ bottle of fruit juice (58). A Swedish study recently addressed this issue by randomizing 30 healthy individuals to receive a diet supplemented in either nuts or fruit for 2 months each at $+7 \mathrm{kcal} / \mathrm{kg}$ body weight per day (59). No change in hepatic fat content was demonstrated in individuals consuming excess fruit despite an almost 3 -fold increase in fructose intake.

To summarize there is a clear consensus between studies that overfeeding with simple sugars leads to increased levels of hepatic fat and serum TG levels. While there is some evidence that this effect is independent of total calorie intake and weight gain, additional high quality studies are needed to confirm this. Randomized control trial data suggests that fructose and glucose are equally steatogenic. Multiple mechanisms are at play as described in Figure 2, however DNL appears to be the dominant pathway in the case of carbohydrate overfeeding.

\section{The Impact of Fat Ingestion and Excess Fat Consumption on the Liver}

An increase in dietary fat increases hepatic fat in normal weight and overweight/obese individuals as shown in a number of studies involving either an isocaloric or hypercaloric diet. However, the magnitude and distribution of fat depot expansion varies significantly according to the type of dietary fat consumed (Supplementary Table 2).

\section{Isocaloric Diet}

In 10 obese women, liver, intra-abdominal, and subcutaneous fat were measured at baseline and after a 2 week isocaloric period consisting of a diet with low vs. high fat, containing either $16 \% \mathrm{E}$ or $56 \% \mathrm{E}$ of total energy intake as fat (60). Liver fat decreased by $20 \pm 9 \%$ and increased by $35 \pm 21 \%$ with the low- and high fat diet, respectively. Fasting serum insulin showed similar trends decreasing with the low fat diet and increasing with the high fat diet. Intra-abdominal and subcutaneous fat were unchanged (60). Similar findings were found in 20 overweight men allocated to a 3 week low or high fat diet containing either $20 \% \mathrm{E}$ or $55 \% \mathrm{E}$ fat with liver fat, decreasing by $13 \%$ and increasing by $17 \%$ in the low and high fat groups, respectively (61).

The type of dietary fat consumed is relevant. A total of 67 abdominally obese subjects (15\% with T2D) were randomly assigned to a 10 week isocaloric diet high in vegetable $n-6$ PUFAs (PUFA diet) vs. SFA mainly from butter (SFA diet) without modifying the macronutrient intake (62). Body weight slightly increased with no between-group differences however liver fat, measured by ${ }^{1} \mathrm{H}$-MRS, reduced in the PUFA group and increased in the SFA group. No differences were observed for subcutaneous or visceral adipose tissue. Change in liver fat was positively associated with change in serum SFAs. Metabolic profiles including plasma lipid levels were lower during the PUFA diet than during the SFA diet (62).

\section{Hypercaloric Diet}

LIPOGAIN was a double-blind, parallel group randomized trial examining 39 young, normal weight individuals investigating the importance of dietary fat composition for ectopic fat storage (44). Participants were overfed muffins that were identical in 
TABLE 2 | Summary of studies examining the impact of fat over-feeding on liver fat.

\begin{tabular}{|c|c|c|c|c|c|c|c|}
\hline References & Participants & Design & Intervention & Duration & Body weight (kg) & Liver fat ( $\left.{ }^{1} \mathrm{H}-\mathrm{MRS} / \mathrm{MRI} \%\right)$ & ALT, AST (U/L) \\
\hline \multicolumn{8}{|c|}{ Shorter duration ( $\leq 1$ week) } \\
\hline $\begin{array}{l}\text { van der Meer } \\
\text { et al. (39) }\end{array}$ & $\begin{array}{l}\text { Non-diabetic men } \\
(n=15)\end{array}$ & One group & $\begin{array}{l}\text { Habitual diet }+800 \mathrm{ml} \text { cream/day }- \text { high fat } \\
\text { high energy (HFHE) diet [added 2,632 kcl/day } \\
\text { (94\% fat)] }\end{array}$ & 3 days & $\begin{array}{l}p=\mathrm{ns} \text { for } \mathrm{BMl} \text { (no } \\
\text { data on body } \\
\text { weight) }\end{array}$ & $\begin{array}{l}\mathrm{a}+112 \%(2.01 \pm 1.79 \rightarrow 4.26 \pm 2.78), p= \\
0.001\end{array}$ & $A L T, A S T: p=\mathrm{ns}$ \\
\hline $\begin{array}{l}\text { Wulan et al. } \\
\text { (40) }\end{array}$ & $\begin{array}{l}\text { Non-diabetic men } \\
\text { 1. South Asian } \\
(n=10) \\
\text { 2. White }(n=10)\end{array}$ & One group & $\begin{array}{l}\text { High fat diet (+50\% EE: } 60 \% \text { E fat, 25\%E CHO, } \\
15 \% \text { E protein) }\end{array}$ & 4 days & & $\begin{array}{l}\text { South Asian }+33 \%(p<0.05) \\
\text { White }+34 \%(p<0.05) \\
\text { Ethnicities, } p=\text { ns }\end{array}$ & \\
\hline $\begin{array}{l}\text { Wulan et al. } \\
(41)\end{array}$ & $\begin{array}{l}\text { Non-diabetic men } \\
\text { 1. South Asian } \\
(n=10) \\
\text { 2. White }(n=10)\end{array}$ & One group & $\begin{array}{l}\text { High fat diet (+50\% EE: } 60 \% \mathrm{E} \text { fat, } 25 \% \mathrm{E} \mathrm{CHO} \text {, } \\
15 \% \mathrm{E} \text { protein) } \\
\text { Subjects stayed in respiration chamber } \\
\text { mimicking a sedentary lifestyle. }\end{array}$ & 3 days & & $\begin{array}{l}\text { South Asian } 1.7 \pm 1.4 \rightarrow 2.7 \pm 1.9(p<0.05) \\
\text { White } 2.6 \pm 3.5 \rightarrow 3.1 \pm 4.9(p<0.05) \\
\text { Ethnicities, } p=\text { ns }\end{array}$ & \\
\hline \multicolumn{8}{|c|}{ Longer duration (> 1 week) } \\
\hline $\begin{array}{l}\text { Kechagias } \\
\text { et al. (42) }\end{array}$ & $\begin{array}{l}\text { Non-diabetic } \\
\text { individuals }(n=18)\end{array}$ & One group & $\begin{array}{l}\text { 2x fast-food based meals/day (aim 5-15\% } \\
\text { weight gain) } \\
\text { Baseline (mean): Kcal/day 2,273, CHO 48\%E, } \\
\text { fat } 36 \% \mathrm{E} \text { ( } 38 \% \text { sat fat) } \\
\text { Study (mean): Kcal/day 5,753, CHO 45\%E, fat } \\
43 \% \mathrm{E}(43 \% \text { sat fat) }\end{array}$ & 4 weeks & ${ }^{a}+6.4(p<0.001)$ & ${ }^{a} 1.1 \pm 1.9 \rightarrow 2.8 \pm 4.8(p=0.003)$ & $\begin{array}{l}\text { ALT: } 22.1 \pm 11 \rightarrow \\
69.3 \pm 76(p= \\
0.01) \\
\text { AST: } 28.1 \pm 12 \\
\rightarrow 39.6 \pm 23(p \\
=0.07)\end{array}$ \\
\hline $\begin{array}{l}\text { Rietman et al. } \\
(43)\end{array}$ & $\begin{array}{l}\text { Non-diabetic lean } \\
\text { individuals }(n=29)\end{array}$ & $\begin{array}{l}\text { Randomized } \\
\text { Cross-over }\end{array}$ & $\begin{array}{l}\text { 1. High fat diet }+ \text { normal protein }(N P) \\
\text { 2. High fat diet }+ \text { high protein }(H P)\end{array}$ & 2 weeks & $\begin{array}{l}p=\text { ns vs. WM } \\
p=\text { ns NP vs. HP }\end{array}$ & $\begin{array}{l}p=\text { ns vs. WM } \\
p=\text { ns NP vs. HP }\end{array}$ & \\
\hline $\begin{array}{l}\text { Rosquist et al. } \\
\text { (44) }\end{array}$ & $\begin{array}{l}\text { Non-diabetic } \\
\text { normal weight } \\
\text { individuals }(n=39)\end{array}$ & $\begin{array}{l}\text { Randomized } \\
\text { Parallel } \\
\text { double-blind, } \\
\text { (LIPOGAIN) }\end{array}$ & $\begin{array}{l}\text { Standard diet }+ \\
\text { 1. Muffins high in SFAs (palm oil) } \\
\text { 2. Muffins high in n-6 PUFAs (sunflower oil) } \\
\text { Quantity adjusted for } 3 \% \text { weight gain } \\
\text { Muffins matched for energy, fat, protein, } \\
\text { CHO, cholesterol. }\end{array}$ & 7 weeks & $\begin{array}{l}\text { aSFA }+1.6 \pm 0.96 \\
\text { PUFA }+1.6 \pm 0.85 \\
\text { SFA vs. PUFA, } p \\
=\text { ns }\end{array}$ & $\begin{array}{l}\text { SFA }+0.56 \pm 1.0 \\
\text { PUFA }+0.04 \pm 0.24 \\
\text { SFA vs. PUFA, } p=0.033\end{array}$ & \\
\hline $\begin{array}{l}\text { Johannsen } \\
\text { et al. (45) }\end{array}$ & $\begin{array}{l}\text { Non-diabetic } \\
\text { individuals }(n=29)\end{array}$ & One group & $\begin{array}{l}+40 \% \text { EE: } 41 \% \mathrm{E} C H O, 44 \% \mathrm{E} \text { fat }(40 \% \text { SFAs), } \\
15 \% \text { E protein }\end{array}$ & 8 weeks & $+7.6 \pm 2.1$ & $1.5 \pm 0.6 \rightarrow 2.19 \pm 1.0(p<0.01)$ & $\begin{array}{l}\text { ALT: } 27.4 \pm 12.4 \\
\rightarrow 38.3 \pm 18.9(p \\
<0.001)\end{array}$ \\
\hline $\begin{array}{l}\text { Rosquist et al. } \\
\text { (46) }\end{array}$ & $\begin{array}{l}\text { Non-diabetic } \\
\text { overweight } \\
\text { individuals }(n=60)\end{array}$ & $\begin{array}{l}\text { Randomized } \\
\text { Parallel } \\
\text { double-blind, } \\
\text { (LIPOGAIN-2) }\end{array}$ & $\begin{array}{l}\text { Standard diet }+ \\
\text { 1. Muffins high in SFAs (palm oil) } \\
\text { 2. Muffins high in n-6 PUFAs } \\
\text { (sunflower oil) } \\
\text { Quantity adjusted for } 3 \% \text { weight gain } \\
\text { Muffins matched for energy, fat, protein, } \\
\text { CHO, cholesterol }\end{array}$ & 8 weeks & $\begin{array}{l}\text { aSFA } \\
+2.31 \pm 1.38 \\
\text { PUFA } \\
+2.01 \pm 1.90 \\
\text { SFA vs. PUFA, } p \\
=\text { ns }\end{array}$ & $\begin{array}{l}\text { aSFA }+53 \%(+1.54 \pm 2.0) \\
\text { PUFA-2\% }(-0.09 \pm 1.55) \\
\text { SFA vs. PUFA, } p=0.001\end{array}$ & $\begin{array}{l}\text { ALT }(m k a t / L): \\
\text { SFA }+0.08 \pm 0.18, \\
\text { PUFA-0.01 } \pm 0.14, \\
p=0.035\end{array}$ \\
\hline
\end{tabular}

All results show mean \pm SEM unless stated otherwise.

${ }^{a}$ Mean $\pm S D$.

${ }^{b}$ Median (interquartile range).

${ }^{1} \mathrm{H}$-MRS, magnetic resonance spectroscopy; MRI, magnetic resonance imaging; ALT, alanine transaminase; AST, aspartate aminotransferase; BMI, body mass index; EE, excess energy; W, weight maintenance diet; CHO, carbohydrate;

SFA, saturated fatty acids; n-6 PUFA, omega 6 polyunsaturated fatty acids. 
TABLE 3 | Summary of studies of both fat and carbohydrate over-feeding on liver fat.

\begin{tabular}{|c|c|c|c|c|c|c|c|}
\hline References & Participants & Design & Intervention & Duration & Body weight (kg) & Liver fat ( $\left.{ }^{1} \mathrm{H}-\mathrm{MRS} / \mathrm{MRI} \%\right)$ & ALT, AST (U/L) \\
\hline \multicolumn{8}{|c|}{ Shorter duration ( $\leq 1$ week) } \\
\hline $\begin{array}{l}\text { Sobrecases } \\
\text { et al. (47) }\end{array}$ & $\begin{array}{l}\text { Non-diabetic men } \\
(n=37)\end{array}$ & $\begin{array}{l}\text { Randomized } \\
\text { Parallel }\end{array}$ & $\begin{array}{l}\text { 1. } \mathrm{HFrD} \text { (+3.5 g fructose } / \mathrm{kg} / \mathrm{FFM},+35 \% \\
\text { energy) } \\
\text { 2. High fat diet (Fat) (+30\%E as fat) } \\
\text { 3. High-fructose high-fat diet (FruFat) ( } 3.5 \mathrm{~g} \\
\text { fructose } / \mathrm{kg} / \mathrm{FFM}+30 \% \mathrm{E} \text { as fat) }\end{array}$ & 7 days & $p=\mathrm{ns}$ & $\begin{array}{l}\text { HFrD }+16 \% \\
\text { Fat }+86 \% \\
\text { Frufat }+133 \% \\
\text { FruFat vs. HFrD } p<0.05 \\
\text { FruFat vs. Fat } p<0.05\end{array}$ & $\begin{array}{l}\text { ALT: Only the } \\
\text { FruFat diet led to } \\
\text { ALT increase }\end{array}$ \\
\hline $\begin{array}{l}\text { Lecoultre } \\
\text { et al. (48) }\end{array}$ & $\begin{array}{l}\text { Non-diabetic men } \\
(n=55)\end{array}$ & $\begin{array}{l}\text { Randomized } \\
\text { Parallel }\end{array}$ & $\begin{array}{l}\text { WM diet + either: } \\
1.5 / 3 / 4 \mathrm{~g} \text { fructose } / \mathrm{kg} / \mathrm{FFM}(\mathrm{F} 1.5, \mathrm{~F} 3, \mathrm{~F} 4) \\
3 \mathrm{~g} / \mathrm{kg} / \text { day glucose (G3.0) } \\
\text { 30\%E as SFAs (Fat 30\%) }\end{array}$ & $6-7$ days & $\begin{array}{l}p=\text { ns all group } \\
\text { vs. controls }\end{array}$ & $\begin{array}{l}\text { a/HCL }(\mathrm{mmol} / \mathrm{kg}): \\
\text { F3 } 9.0 \pm 8.0 \rightarrow 18.5 \pm 2.5(p<0.01) \\
\text { F4 } 13.1 \pm 7.9 \rightarrow 23.7 \pm 15.2(p<0.01) \\
\text { Fat } 30 \% 11.6 \pm 8.0 \rightarrow 21.9 \pm 17.2(p<0.05) \\
\text { F1.5 } 6.0 \pm 3.0 \rightarrow 5.7 \pm 2.5(p=n s) \\
\text { G3.0 } 12.9 \pm 15.0 \rightarrow 16.1 \pm 15.1(p=n s) \\
\text { F3 vs. F1/F4 vs. F1/Glu3.0 vs. F3 all } p<0.05\end{array}$ & \\
\hline $\begin{array}{l}\text { Surowska } \\
\text { et al. (49) }\end{array}$ & $\begin{array}{l}\text { Non-diabetic } \\
\text { individuals }(n=12)\end{array}$ & $\begin{array}{l}\text { Randomized } \\
\text { Cross-over }\end{array}$ & $\begin{array}{l}\text { Hypercaloric diet (+45\% EE) + high in sucrose } \\
\text { 1. Low protein, high fat hypercaloric diet } \\
\text { (LP-HF): } 5 \% \text { E protein, } 25 \% \text { E fat } \\
\text { 2. High protein, low fat hypercaloric diet } \\
\text { (HP-LF): } 20 \% \text { E protein, } 10 \% \text { E fat }\end{array}$ & $\begin{array}{l}6 \text { days } \\
4-8 \text { week } \\
\text { washout period }\end{array}$ & $\begin{array}{l}\mathrm{LP}-\mathrm{HF}+0.7 \pm 0.1 \\
(p=n s) \\
\mathrm{HP}-\mathrm{LF}+1.4 \pm 0.2 \\
(p<0.01)\end{array}$ & $\begin{array}{l}\text { IHCL }(\mathrm{H}-\mathrm{MRS})(\mathrm{mmo} / \mathrm{kg} \mathrm{ww}): \\
\text { LP-HF: } 25.0 \pm 3.6 \rightarrow 147.1 \pm 26.9 \\
\text { HP-LF: } 30.3 \pm 7.7 \rightarrow 57.8 \pm 14.8 \\
\text { Two-way ANOVA with interaction } p<0.001 \\
\text { overfeeding } x \text { protein/fat content }\end{array}$ & \\
\hline \multicolumn{8}{|c|}{ Longer duration (> 1 week) } \\
\hline $\begin{array}{l}\text { Luukkonen } \\
\text { et al. }(50)\end{array}$ & $\begin{array}{l}\text { Non-diabetic } \\
\text { individuals }(n=38)\end{array}$ & $\begin{array}{l}\text { Randomized } \\
\text { Parallel }\end{array}$ & $\begin{array}{l}\text { Hypercaloric diet (1,000 excess kcal/day) } \\
\text { 1. SAT: Mainly SFAs (76\%E SFAs, } 21 \% \mathrm{E} \\
\text { MUFAs, } 3 \% \mathrm{E} \text { PUFAs) } \\
\text { 2. UNSAT: Mainly USFAs ( } 57 \% \text { E MUFAs, } \\
\text { 22\%E PUFAs, } 21 \% \mathrm{E} \text { SFAs) } \\
\text { 3. CARB: } 100 \% \text { E simple sugars }\end{array}$ & 3 weeks & $p=n s$ & $\begin{array}{l}\text { SAT }+55 \%(4.9 \pm 6.6 \rightarrow 7.6 \pm 8.8), p< \\
0.001 \\
\text { UNSAT }+15 \%(4.8 \pm 4.9 \rightarrow 5.5 \pm 4.8), p< \\
0.02 \\
\text { CARB }+33 \%(4.3 \pm 4.7 \rightarrow 5.7 \pm 5.4), p< \\
0.02 \\
\text { SAT vs. UNSAT, } p<0.01 \\
\text { b Newly synthesized palmitate in VLDL TG } \\
(\mu \text { mol/L): } \\
\text { CARB }+33 \%(96[47-116] \rightarrow 190[61-303]), p \\
<0.05 \\
\text { UNSAT \& CARB, } p=\text { ns }\end{array}$ & $\begin{array}{l}\text { ALT: SAT }+25 \% \\
(28 \pm 15 \rightarrow \\
35 \pm 18), p<0.05 \\
\text { UNSAT \& CARB, } p \\
=\mathrm{ns} \\
\text { AST: SAT }+12 \% \\
(26 \pm 5 \rightarrow \\
29 \pm 6), p<0.05 \\
\text { UNSAT \& CARB, } p \\
=n s\end{array}$ \\
\hline $\begin{array}{l}\text { Koopman } \\
\text { et al. (25) }\end{array}$ & $\begin{array}{l}\text { Non-diabetic lean } \\
\text { men }(n=36)\end{array}$ & $\begin{array}{l}\text { Randomized } \\
\text { Parallel }\end{array}$ & $\begin{array}{l}\text { Hypercaloric diet ( }+40 \% \text { EE) } \\
\text { 1. High fat high sugar }+\uparrow \text { meal size (HFHS-S) } \\
\text { 2. High fat high sugar }+\uparrow \text { meal frequency } \\
\text { (HFHS-F) } \\
\text { 3. High sugar }+\uparrow \text { meal size (HS-S) } \\
\text { 4. High sugar }+\uparrow \text { meal frequency (HS-F) } \\
\text { Controls: ad libitum diet }\end{array}$ & 6 weeks & $\begin{array}{l}\text { a } B M I\left(\mathrm{~kg} / \mathrm{m}^{2}\right): \\
\text { HFHS-S }+0.6(p< \\
0.05) \\
\text { HFHS-F }+0.9(p< \\
0.01) \\
\text { HS-S }+0.8(p< \\
0.001) \\
\text { HS-F }+0.5(p= \\
\text { ns) (no data on } \\
\text { body weight) }\end{array}$ & $\begin{array}{l}\text { aHFHS-F }+45 \%(0.98 \pm 0.91 \rightarrow 1.38 \pm 1.26 \\
p<0.05) \\
\text { HS-F }+110 \%(1.49 \pm 0.95 \rightarrow 3.10 \pm 2.16, p \\
<0.05) \\
\text { HFHS-F vs. HS-F } p=n s \\
\text { HFHS-S }+19 \%(0.85 \pm 0.32 \rightarrow 1.05 \pm 1.26 \\
p=n s) \\
\text { HS-S }+14 \%(0.80 \pm 0.45 \rightarrow 0.93 \pm 1.04, p \\
=n s)\end{array}$ & \\
\hline
\end{tabular}

All results show mean \pm SEM unless stated otherwise.

a Mean $\pm S D$.

${ }^{b}$ Median (interquartile range).

${ }^{1}$ H-MRS, magnetic resonance spectroscopy; MRI, magnetic resonance imaging; ALT, alanine transaminase; AST, aspartate aminotransferase; HFrD, high fructose diet; FFM, fat free mass; WM, weight maintenance diet; SFA, saturated fatty acids; IHCL, intrahepatocellular lipids; EE, excess energy; BMI, body mass index; MUFA, monounsaturated fatty acids; PUFA, polyunsaturated fatty acids; VLDL, very low density lipoprotein; TG, triglycerides; ANOVA, analysis of variance. 
composition except for the type of fat: containing either high levels of SFA (palm oil) or n-6 PUFA (sunflower oil). Participants were provided an additional $750 \mathrm{kcal} /$ day for 7 weeks to their habitual diet to induce identical weight gain $(\sim 2.2 \%$ increase, $1.6 \mathrm{~kg}$ ). SFAs markedly increased liver fat and caused a 2 -fold larger increase in VAT compared with PUFAs. The increase in liver fat was positive correlated with increases in SFA as measured by plasma palmitic acid. Conversely, PUFAs caused a nearly 3fold larger increase in lean tissue than SFAs (lean tissue: fat added: 1:1 with PUFAs, 1:4 with SFAs) (44). Although PUFAs, in contrast to SFAs, were noted to be associated with reductions in atherogenic lipoproteins, the weight gain observed with both types of fat overfeeding was associated with hyperinsulinaemia and increased biomarkers of endothelial dysfunction (63).

Recently, Rosqvist et al., conducted a further double-blind randomized trial (LIPOGAIN-2), with a similarly designed intervention comparing overfeeding with SFA from palm oil vs. PUFA from sunflower oil (46). Overfeeding was for an 8 week period, followed by 4 weeks of caloric restriction but in an overweight, middle-aged group (mean age 42 years and BMI 28 $\mathrm{kg} / \mathrm{m}^{2}$ ) compared with a lean, young population in the earlier study (mean age 27 years and BMI $20, \mathrm{~kg} / \mathrm{m}^{2}$ ). The differential effects on liver fat and blood lipid levels were even more distinct. The weight gain observed was $2-2.3 \mathrm{~kg}$ and although no differential effect was seen on VAT, pancreatic fat or total body fat, a differential effect was seen on liver enzymes and liver fat, increasing by $50 \%$ with SFA but unchanged with PUFA.

\section{GIP}

The intestinal incretin, GIP seems to play an important role in mediating the impact of saturated fat on the liver. NASH patients exhibit a prolonged elevation of GIP after saturated fat ingestion and this increased GIP response to saturated fat intake is associated with the severity of liver disease (21).

In summary both iso- and hyper-caloric diets have consistently shown that a high fat diet leads to increased levels of hepatic steatosis. Furthermore, randomized control trial data has shown that SFAs lead to significant increases in liver fat, whereas PUFAs are protective in a setting of identical weight gain. This was found to be true for both normal weight and overweight individuals.

\section{Studies Comparing Carbohydrate and Fat Overfeeding}

A small number of randomized studies have compared the impact of fat or carbohydrate overfeeding on liver fat (Table 3). Studies are heterogenous in design, but there is a general trend that overfeeding with SFAs is associated with the greatest risk of hepatic steatosis and increase in transaminases, independent of changes in body weight $(47,50)$. Luukkonen et al. assigned 38 individuals to receive a hypercaloric diet containing either $100 \%$ simple sugars, mainly saturated fat, or mainly unsaturated fat for 3 weeks (50). Lipolysis and DNL were measured under basal conditions and during a euglycaemic hyperinsulinaemic clamp to measure insulin sensitivity. Overfeeding saturated fat increased IHTG more $(+55 \%)$ than unsaturated fat $(+15 \%, p<$ 0.05 ), while carbohydrates increased IHTG $+33 \%$. Importantly, carbohydrates increased liver fat by stimulating DNL (+98\%) while saturated fat did so by significantly increasing the rate of lipolysis (unsaturated fat did not). Additionally, saturated fat induced insulin resistance and endotoxemia and significantly increased multiple plasma ceramides. The diets had also had distinct effects on adipose tissue gene expression (64). Clearly, the metabolic pathways through which different macronutrients increase liver fat are different (50). Finally it is important to note that where overfeeding studies were followed by a hypocaloric diet, changes in weight gain, adverse lipid profiles and liver fat content were all reversed $(35,46)$.

\section{Influence of Protein Intake on Risk of NAFLD}

The vast majority of epidemiological or mechanistic studies relating to NAFLD have examined carbohydrate and fat intake and/or metabolism but there is emerging evidence that dietary protein intake and specific amino acid patterns is relevant in the pathogenesis of NAFLD (65).

Several overfeeding studies have examined the influence of a hypercaloric diet, with a high protein content, on liver fat accumulation. Bortolotti et al. demonstrated supplementing a high fat diet with protein led to a statistically significant attenuation ( $\sim 22 \%)$ in liver fat accumulation induced by the high fat diet despite the additional energy (66). A further study of a high fat, hypercaloric diet, with a normal vs. high protein intake demonstrated that the higher protein intake tended to lower liver fat, circulating TG concentration and fat mass while increasing fat-free mass (43). A similar finding was observed supplementing a high fructose diet with essential amino acids. This led to a statistically significant attenuation $(\sim 16 \%$ reduction $)$ in liver fat accumulation when compared with a high fructose diet alone (33). The mechanisms through which protein or amino acid supplementation may attenuate liver fat accumulation are not yet fully understood.

\section{MEDIATORS OF THE OVERFEEDING RESPONSE}

There are many factors that may influence the response to overfeeding, and thus NAFLD risk, which include the genetic background of the individual (genetic risk of either obesity and/or NAFLD) as well as baseline characteristics including age, sex, BMI, insulin sensitivity, metabolic health status, small for gestational age etc.

\section{Genetic and Epigenetic Factors May Modulate the Response to Overfeeding}

There is evidence that the genetic background of an individual influences the variability of the weight gain and fat storage with caloric excess. This is also likely to apply for liver fat deposition with energy excess. Epidemiological, familial, and twin studies have demonstrated NAFLD has a strong genetic predisposition. Genome-wide association studies led to the identification of the major inherited determinants of hepatic fat accumulation: patatin-like phospholipase domain-containing (PNPLA3) I148M 
gene and transmembrane 6 superfamily member 2 (TM6SF2) E167K gene variants (regulating mobilization of TGs from lipid droplets and VLDL secretion, respectively) (67, 68). More recently membrane bound $O$-acyltransferase domain-containing 7 (MBOAT7), has also been identified (69). These are undoubtedly major determinants of inter-individual differences in liver steatosis, and susceptibility to progressive NASH, yet likely only account for $<10 \%$ of inherited variability. Their relevance has not yet been assessed in overfeeding studies.

Perhaps more commonly implicated are epigenetic mechanisms, whereby there is interaction between nutrients and the genome by modifications such as DNA methylation, histone modifications, and miRNAs targeting mRNA, that affect gene expression without altering the DNA sequence. These fields of nutrigenomic and nutriepigenomics are increasingly emerging (70).

\section{Ethnic-Specific Differences in Response to Overfeeding}

Differences in body composition and liver fat deposition are apparent between white Europeans, South Asian and black Africans matched for age, sex, and BMI. South Asian populations are typically characterized by disproportionately more visceral fat accumulation and higher intrahepatic and intramyocellular lipid content than BMI-matched white Europeans), contributing to insulin resistance and higher T2D risk (71-73). In contrast, black African-Caribbean populations consistently have lower levels of liver fat and VAT and higher levels of subcutaneous fat, even after adjustment for BMI or waist circumference $(74,75)$, although paradoxically despite lower ectopic fat, marked insulin resistance is reported (76). In this population insulin resistance is more strongly associated with abdominal subcutaneous rather than visceral fat $(77,78)$ and African-Caribbean populations appear more sensitive to the negative effects of ectopic fat, particularly intrapancreatic lipid accumulation (79). Considering South Asians have this lower capacity to store fat in SAT, they may be more susceptible to the negative effects of overfeeding with greater ectopic fat deposition including the liver. When subjected to 4 days of overfeeding ( $50 \%$ excess energy need) with a high fat diet $(60 \% \mathrm{E}$ energy from fat), South Asian and Caucasian men with the same body fat percentage, and similar liver fat content at baseline, showed similar increases in liver fat (33 and 34\% respectively) as described in Table 2, Supplementary Table 2 (40). However, the high fat diet had more adverse effects on the lipid profile in the South Asians compared with the Caucasians (41). Longer duration studies in South Asians may reveal different insights while differential effects between overfeeding in Caucasian and African-Caribbean populations are unknown.

\section{Counteracting the Effects of Overfeeding With Exercise}

There is a wealth of epidemiological, cross-sectional and interventional evidence linking physical activity and/or physical inactivity, aerobic capacity, and exercise to liver fat and susceptibility to/protection from NAFLD development and progression. Significantly, exercise can modulate liver fat independent of changes in fat mass (80). Habitual physical activity, cardiorespiratory fitness, and exercise have convincingly been shown to be important in regulating liver fat as shown in a series of cross-sectional and interventional studies (12$14,81,82$ ). In a randomized controlled trial of 50 participants, we demonstrated that supervised moderate-intensity exercise, improving cardiorespiratory fitness with small reductions in body weight, led to significantly lower liver fat and improvements in peripheral (but not hepatic) insulin sensitivity (81). These improvements were not sustained following cessation of the exercise supervision (82). Conversely, we demonstrated that 2 weeks of physical inactivity (reducing daily step count from $>10,000$ to $<1,500 /$ day) induced liver fat accumulation and other features of metabolic syndrome (12). Furthermore, we showed that habitual inactivity influences liver fat, with every additional hour of daily sedentary time associated with a $1.15 \%(95 \%$ confidence interval, 1.14-1.50\%) higher liver fat content (normal liver fat $<5.56 \%$; NAFLD $>5.56 \%$ ). (13) Thus, increases or reductions in physical activity are likely to influence the liver's response to nutrient excess/overfeeding. Considering the above evidence, unsurprisingly overfeeding studies have incorporated daily vigorous-intensity exercise into study designs to offset the positive energy balance and counteract the simultaneous imposition of overfeeding with physical inactivity, designed to be representative of modern Western lifestyles $(83,84)$. Exercise provides this counterbalance at a whole-body and adipose tissue level by preventing the hyperinsulinaemic response and modifying the expression of key adipose tissue metabolic and insulin signaling genes and proteins (83). How exercise may attenuate liver fat accumulation with overfeeding $(+/-$ inactivity) has yet to be examined.

\section{CONCLUSIONS}

Dietary intervention studies including overfeeding studies are diverse in their time frames, intervention (different types, subtypes, quantities of macronutrients, isocaloric/hypercaloric), design (parallel/non-parallel studies), control groups, baseline population demographics, and primary outcomes. Some induced weight gain, whilst others did not. Background genetic, ethnicitydependent, and other baseline factors particularly baseline health and fitness/activity levels will modulate the liver's response to overfeeding. The studies considered here were consistent only in that they all used MRI or MRS to determine changes in liver fat, which is now the gold standard. While this is a narrative review only and no formal evaluation of the quality of evidence was made, we identified consistency among studies reporting an association between increased saturated fat and simple sugar intake and hepatic steatosis. Meta-analysis data suggests that saturated fat can lead to increased liver fat content even in the context of an isocaloric diet. PUFAs have also been consistently shown to have a favorable effect on liver steatosis. It is still unclear whether there is a difference in the ability of fat or carbohydrate to lead to greater levels of IHTGs compared to one another. There is some evidence to support a low GI diet which requires further validation. 
There are currently no pharmacological approved agents for NAFLD despite significant investment in this field, and weight loss remains the only proven management for this incredibly prevalent condition. Prevention and disease modification through dietary recommendations, which consider macronutrient intake, have huge potential to be benefit patients. High quality, randomized control studies with adequate baseline controls and longitudinal follow up are essential and urgently needed to provide evidence-based guidance which may to help prevent morbidity and mortality from NAFLD and its associated metabolic conditions.

\section{REFERENCES}

1. Bray GA, Bouchard C. The biology of human overfeeding: a systematic review. Obes Rev. (2020) 21:e13040. doi: 10.1111/obr.13040

2. European Association for the Study of the Liver (EASL), European Association for the Study of Diabetes (EASD) \& European Association for the Study of Obesity (EASO). EASL-EASD-EASO Clinical Practice Guidelines for the management of non-alcoholic fatty liver disease. Diabetologia. (2016) 59:1121-40. doi: 10.1007/s00125-016-3902-y

3. NICE guideline [NG49]. Non-Alcoholic Fatty Liver Disease (NAFLD): Assessment and Management (2016).

4. Younossi ZM, Koenig AB, Abdelatif D, Fazel Y, Henry L, Wymer M. Global epidemiology of nonalcoholic fatty liver disease-Meta-analytic assessment of prevalence, incidence, and outcomes. Hepatology. (2016) 64:7384. doi: 10.1002/hep.28431

5. Singh S, Allen AM, Wang Z, Prokop LJ, Murad MH, Loomba R. Fibrosis progression in nonalcoholic fatty liver vs nonalcoholic steatohepatitis: a systematic review and meta-analysis of pairedbiopsy studies. Clin Gastroenterol Hepatol. (2015) 13:643-54.e1-9, quiz e39-40. doi: 10.1016/j.cgh.2014.04.014

6. Kawada N, Imanaka K, Kawaguchi T, Tamai C, Ishihara R, Matsunaga $\mathrm{T}$, et al. Hepatocellular carcinoma arising from noncirrhotic nonalcoholic steatohepatitis. J Gastroenterol. (2009) 44:1190-4. doi: 10.1007/s00535-009-0112-0

7. Kotronen A, Seppala-Lindroos A, Bergholm R, Yki-Jarvinen H. Tissue specificity of insulin resistance in humans: fat in the liver rather than muscle is associated with features of the metabolic syndrome. Diabetologia. (2008) 51:130-8. doi: 10.1007/s00125-007-0867-x

8. Marchesini G, Brizi M, Bianchi G, Tomassetti S, Bugianesi E, Lenzi M, et al. Nonalcoholic fatty liver disease: a feature of the metabolic syndrome. Diabetes. (2001) 50:1844-50. doi: 10.2337/diabetes.50.8.1844

9. Fabbrini E, Magkos F, Mohammed BS, Pietka T, Abumrad NA, Patterson BW, et al. Intrahepatic fat, not visceral fat, is linked with metabolic complications of obesity. Proc Natl Acad Sci USA. (2009) 106:154305. doi: 10.1073/pnas.0904944106

10. Hydes TJ, Summers N, Brown E, Alam U, Thomaides-Brears H, Wilding JPH, et al. Mechanisms, screening modalities and treatment options for individuals with non-alcoholic fatty liver disease and type 2 diabetes. Diabet Med. (2020) 37:1793-806. doi: 10.1111/dme.14356

11. Ludwig J, Viggiano TR, McGill DB, Oh BJ. Nonalcoholic steatohepatitis: Mayo clinic experiences with a hitherto unnamed disease. Mayo Clin Proc. (1980) 55:434-8.

12. Bowden Davies KA, Sprung VS, Norman JA, Thompson A, Mitchell KL, Halford JCG, et al. Short-term decreased physical activity with increased sedentary behaviour causes metabolic derangements and altered body composition: effects in individuals with and without a firstdegree relative with type 2 diabetes. Diabetologia. (2018) 61:128294. doi: 10.1007/s00125-018-4603-5

13. Bowden Davies KA, Sprung VS, Norman JA, Thompson A, Mitchell KL, Harrold JOA, et al. Physical activity and sedentary time: association with metabolic health and liver fat. Med Sci Sports Exerc. (2019) 51:116977. doi: 10.1249/MSS.0000000000001901

\section{AUTHOR CONTRIBUTIONS}

$\mathrm{TH}, \mathrm{UA}$, and DC all drafted and reviewed the manuscript and created the figures. TH constructed the tables. All authors contributed to the article and approved the submitted version.

\section{SUPPLEMENTARY MATERIAL}

The Supplementary Material for this article can be found online at: https://www.frontiersin.org/articles/10.3389/fnut.2021. 640557/full\#supplementary-material

14. Bowden Davies KA, Pickles S, Sprung VS, Kemp GJ, Alam U, Moore $\mathrm{DR}$, et al. Reduced physical activity in young and older adults: metabolic and musculoskeletal implications. Ther Adv Endocrinol Metab. (2019) 10:2042018819888824. doi: 10.1177/2042018819888824

15. Chalasani N, Younossi Z, Lavine JE, Charlton M, Cusi K, Rinella M, et al. The diagnosis and management of nonalcoholic fatty liver disease: practice guidance from the American association for the study of liver diseases. Hepatology. (2018) 67:328-57. doi: 10.1002/hep.29367

16. Kim JY, van de Wall E, Laplante M, Azzara A, Trujillo ME, Hofmann SM, et al. Obesity-associated improvements in metabolic profile through expansion of adipose tissue. J Clin Invest. (2007) 117:2621-37. doi: 10.1172/JCI31021

17. Scott RA, Fall T, Pasko D, Barker A, Sharp SJ, Arriola L, et al. Common genetic variants highlight the role of insulin resistance and body fat distribution in type 2 diabetes, independently of obesity. Diabetes. (2014) 63:437887. doi: $10.2337 / \mathrm{db} 14-0319$

18. Taylor R, Holman RR. Normal weight individuals who develop type 2 diabetes: the personal fat threshold. Clin Sci. (2015) 128:405-10. doi: 10.1042/CS20140553

19. Gray SL, Vidal-Puig AJ. Adipose tissue expandability in the maintenance of metabolic homeostasis. Nutr Rev. (2007) 65:S712. doi: 10.1111/j.1753-4887.2007.tb00331.x

20. Smith GI, Shankaran M, Yoshino M, Schweitzer GG, Chondronikola M, Beals JW, et al. Insulin resistance drives hepatic de novo lipogenesis in nonalcoholic fatty liver disease. J Clin Investig. (2020) 13:4165. doi: 10.1172/JCI134165

21. Musso G, Gambino R, Pacini G, De Michieli F, Cassader M. Prolonged saturated fat-induced, glucose-dependent insulinotropic polypeptide elevation is associated with adipokine imbalance and liver injury in nonalcoholic steatohepatitis: dysregulated enteroadipocyte axis as a novel feature of fatty liver. Am J Clin Nutr. (2009) 89:558-67. doi: 10.3945/ajcn.2008.26720

22. Jian C, Luukkonen P, Sädevirta S, Yki-Järvinen H, Salonen A. Impact of short-term overfeeding of saturated or unsaturated fat or sugars on the gut microbiota in relation to liver fat in obese and overweight adults. Clin Nutr. (2020) 40:207-16. doi: 10.1016/j.clnu.2020.05.008

23. Koh A, Molinaro A, Stahlman M, Khan MT, Schmidt C, Manneras-Holm L, et al. Microbially produced imidazole propionate impairs insulin signaling through mTORC1. Cell. (2018) 175:947-61.e17. doi: 10.1016/j.cell.2018.09.055

24. Xiao Q, Garaulet M, Scheer F. Meal timing and obesity: interactions with macronutrient intake and chronotype. Int J Obes. (2019) 43:170111. doi: 10.1038/s41366-018-0284-x

25. Koopman KE, Caan MW, Nederveen AJ, Pels A, Ackermans MT, Fliers E, et al. Hypercaloric diets with increased meal frequency, but not meal size, increase intrahepatic triglycerides: a randomized controlled trial. Hepatology. (2014) 60:545-53. doi: 10.1002/hep.27149

26. Imamura F, Micha R, Wu JHY, de Oliveira Otto MC, Otite FO, Abioye $\mathrm{AI}$, et al. Effects of saturated fat, polyunsaturated fat, monounsaturated fat, and carbohydrate on glucose-insulin homeostasis: a systematic review and meta-analysis of randomised controlled feeding trials. PLoS Med. (2016) 13:e1002087. doi: 10.1371/journal.pmed.1002087

27. Zelber-Sagi S, Nitzan-Kaluski D, Goldsmith R, Webb M, Blendis L, Halpern $\mathrm{Z}$, et al. Long term nutritional intake and the risk for non-alcoholic fatty 
liver disease (NAFLD): a population based study. J Hepatol. (2007) 47:7117. doi: 10.1016/j.jhep.2007.06.020

28. Noureddin M, Zelber-Sagi S, Wilkens LR, Porcel J, Boushey CJ, Le Marchand $\mathrm{L}$, et al. Diet associations with nonalcoholic fatty liver disease in an ethnically diverse population: the multiethnic cohort. Hepatology. (2020) 71:194052. doi: 10.1002/hep.30967

29. Allard JP, Aghdassi E, Mohammed S, Raman M, Avand G, Arendt BM, et al. Nutritional assessment and hepatic fatty acid composition in nonalcoholic fatty liver disease (NAFLD): a cross-sectional study. J Hepatol. (2008) 48:300-7. doi: 10.1016/j.jhep.2007.09.009

30. Cuthbertson DJ, Steele T, Halford JC, Harrold JA, Hamer M, Karpe F, et al. What have human experimental overfeeding studies taught us about adipose tissue expansion and susceptibility to obesity and metabolic complications? Int J Obes. (2017) 41:853-65. doi: 10.1038/ijo.2017.4

31. Lê KA, Ith M, Kreis R, Faeh D, Bortolotti M, Tran C, et al. Fructose overconsumption causes dyslipidemia and ectopic lipid deposition in healthy subjects with and without a family history of type 2 diabetes. Am J Clin Nutr. (2009) 89:1760-5. doi: 10.3945/ajcn.2008.27336

32. Ngo Sock ET, Lê KA, Ith M, Kreis R, Boesch C, Tappy L. Effects of a short-term overfeeding with fructose or glucose in healthy young males. Br J Nutr. (2010) 103:939-43. doi: 10.1017/S0007114509992819

33. Theytaz F, Noguchi Y, Egli L, Campos V, Buehler T, Hodson L, et al. Effects of supplementation with essential amino acids on intrahepatic lipid concentrations during fructose overfeeding in humans. Am J Clin Nutr. (2012) 96:1008-16. doi: 10.3945/ajcn.112.035139

34. Johnston RD, Stephenson MC, Crossland H, Cordon SM, Palcidi E, Cox EF, et al. No difference between high-fructose and high-glucose diets on liver triacylglycerol or biochemistry in healthy overweight men. Gastroenterology. (2013) 145:1016-25.e2. doi: 10.1053/j.gastro.2013.07.012

35. Sevastianova K, Santos A, Kotronen A, Hakkarainen A, Makkonen J, Silander $\mathrm{K}$, et al. Effect of short-term carbohydrate overfeeding and long-term weight loss on liver fat in overweight humans. Am J Clin Nutr. (2012) 96:72734. doi: 10.3945/ajcn.112.038695

36. Lê KA, Faeh D, Stettler R, Ith M, Kreis R, Vermathen P, et al. A 4-wk high-fructose diet alters lipid metabolism without affecting insulin sensitivity or ectopic lipids in healthy humans. Am J Clin Nutr. (2006) 84:13749. doi: 10.1093/ajcn/84.6.1374

37. Silbernagel G, Machann J, Unmuth S, Schick F, Stefan N, Häring HU, et al. Effects of 4-week very-high-fructose/glucose diets on insulin sensitivity, visceral fat and intrahepatic lipids: an exploratory trial. Br J Nutr. (2011) 106:79-86. doi: 10.1017/S000711451000574X

38. Maersk M, Belza A, Stødkilde-Jørgensen H, Ringgaard S, Chabanova E, Thomsen $\mathrm{H}$, et al. Sucrose-sweetened beverages increase fat storage in the liver, muscle, and visceral fat depot: a 6-mo randomized intervention study. Am J Clin Nutr. (2012) 95:283-9. doi: 10.3945/ajcn.111. 022533

39. van der Meer RW, Hammer S, Lamb HJ, Frolich M, Diamant M, Rijzewijk LJ, et al. Effects of short-term high-fat, high-energy diet on hepatic and myocardial triglyceride content in healthy men. J Clin Endocrinol Metab. (2008) 93:2702-8. doi: 10.1210/jc.2007-2524

40. Wulan SN, Schrauwen-Hinderling VB, Westerterp KR, Plasqui G. Liver fat accumulation in response to overfeeding with a high-fat diet: a comparison between South Asian and Caucasian men. Nutr Metab. (2015) 12:18. doi: 10.1186/s12986-015-0015-4

41. Wulan SN, Schrauwen-Hinderling VB, Westerterp KR, Plasqui G. Substrate utilization and metabolic profile in response to overfeeding with a high-fat diet in South Asian and white men: a sedentary lifestyle study. Int J Obes. (2020) 44:136-46. doi: 10.1038/s41366-019-0368-2

42. Kechagias S, Ernersson A, Dahlqvist O, Lundberg P, Lindström T, Nystrom FH. Fast-food-based hyper-alimentation can induce rapid and profound elevation of serum alanine aminotransferase in healthy subjects. Gut. (2008) 57:649-54. doi: 10.1136/gut.2007.131797

43. Rietman A, Schwarz J, Blokker BA, Siebelink E, Kok FJ, Afman LA, et al. Increasing protein intake modulates lipid metabolism in healthy young men and women consuming a high-fat hypercaloric diet. J Nutr. (2014) 144:117480. doi: $10.3945 /$ jn.114.191072

44. Rosqvist F, Iggman D, Kullberg J, Cedernaes J, Johansson HE, Larsson A, et al. Overfeeding polyunsaturated and saturated fat causes distinct effects on liver and visceral fat accumulation in humans. Diabetes. (2014) 63:235668. doi: $10.2337 / \mathrm{db} 13-1622$

45. Johannsen DL, Tchoukalova Y, Tam CS, Covington JD, Xie W, Schwarz JM, et al. Effect of eight weeks of overfeeding on ectopic fat deposition and insulin sensitivity: testing the "adipose tissue expandability" hypothesis. Diabetes Care. (2014) 37:2789-97. doi: 10.2337/dc140761

46. Rosqvist F, Kullberg J, Ståhlman M, Cedernaes J, Heurling K, Johansson HE, et al. Overeating saturated fat promotes fatty liver and ceramides compared with polyunsaturated fat: a randomized trial. J Clin Endocrinol Metab. (2019) 104:6207-19. doi: 10.1210/jc.2019-00160

47. Sobrecases H, Le KA, Bortolotti M, Schneiter P, Ith M, Kreis R, et al. Effects of short-term overfeeding with fructose, fat and fructose plus fat on plasma and hepatic lipids in healthy men. Diabetes Metab. (2010) 36:2446. doi: 10.1016/j.diabet.2010.03.003

48. Lecoultre V, Egli L, Carrel G, Theytaz F, Kreis R, Schneiter P, et al. Effects of fructose and glucose overfeeding on hepatic insulin sensitivity and intrahepatic lipids in healthy humans. Obesity. (2013) 21:7825. doi: 10.1002/oby.20377

49. Surowska A, Jegatheesan P, Campos V, Marques AS, Egli L, Cros J, et al. Effects of dietary protein and fat content on intrahepatocellular and intramyocellular lipids during a 6-day hypercaloric, high sucrose diet: a randomized controlled trial in normal weight healthy subjects. Nutrients. (2019) 11:10209. doi: 10.3390/nu110 10209

50. Luukkonen PK, Sädevirta S, Zhou Y, Kayser B, Ali A, Ahonen L, et al. Saturated fat is more metabolically harmful for the human liver than unsaturated fat or simple sugars. Diabetes Care. (2018) 41:17329. doi: 10.1016/S0168-8278(18)31947-0

51. Winters-van Eekelen E, Verkouter I, Peters HPF, Alssema M, de Roos BG, Schrauwen-Hinderling VB, et al. Effects of dietary macronutrients on liver fat content in adults: a systematic review and meta-analysis of randomized controlled trials. Eur J Clin Nutr. (2020). doi: 10.1038/s41430-020-00778-1

52. Jensen T, Abdelmalek MF, Sullivan S, Nadeau KJ, Green M, Roncal C, et al. Fructose and sugar: a major mediator of non-alcoholic fatty liver disease. $J$ Hepatol. (2018) 68:1063-75. doi: 10.1016/j.jhep.2018.01.019

53. Malik VS, Popkin BM, Bray GA, Després JP, Willett WC, Hu FB. Sugarsweetened beverages and risk of metabolic syndrome and type 2 diabetes: a meta-analysis. Diabetes Care. (2010) 33:2477-83. doi: 10.2337/dc10-1079

54. Imamura F, O'Connor L, Ye Z, Mursu J, Hayashino Y, Bhupathiraju SN, et al. Consumption of sugar sweetened beverages, artificially sweetened beverages, and fruit juice and incidence of type 2 diabetes: systematic review, metaanalysis, and estimation of population attributable fraction. BMJ. (2015) 351:h3576. doi: 10.1136/bmj.h3576

55. Lambertz J, Weiskirchen S, Landert S, Weiskirchen R. Fructose: a dietary sugar in crosstalk with microbiota contributing to the development and progression of non-alcoholic liver disease. Front Immunol. (2017) 8:1159. doi: $10.3389 /$ fimmu.2017.01159

56. Stanhope KL, Schwarz JM, Keim NL, Griffen SC, Bremer AA, Graham $\mathrm{JL}$, et al. Consuming fructose-sweetened, not glucose-sweetened, beverages increases visceral adiposity and lipids and decreases insulin sensitivity in overweight/obese humans. J Clin Invest. (2009) 119:1322-34. doi: 10.1172/JCI37385

57. Bawden S, Stephenson M, Falcone Y, Lingaya M, Ciampi E, Hunter K, et al. Increased liver fat and glycogen stores after consumption of high versus low glycaemic index food: a randomized crossover study. Diabetes Obes Metab. (2017) 19:70-7. doi: 10.1111/dom.12784

58. Walker RW, Dumke KA, Goran MI. Fructose content in popular beverages made with and without high-fructose corn syrup. Nutrition. (2014) 30:92835. doi: 10.1016/j.nut.2014.04.003

59. Agebratt C, Ström E, Romu T, Dahlqvist-Leinhard O, Borga $M$, Leandersson $P$, et al. A randomized study of the effects of additional fruit and nuts consumption on hepatic fat content, cardiovascular risk factors and basal metabolic rate. PLoS ONE. (2016) 11:e0147149. doi: 10.1371/journal.pone.0147149

60. Westerbacka J, Lammi K, Hakkinen AM, Rissanen A, Salminen I, Aro A. Dietary fat content modifies liver fat in overweight nondiabetic subjects. J Clin Endocrinol Metab. (2005) 90:2804-9. doi: 10.1210/jc.2004-1983 
61. van Herpen NA, Schrauwen-Hinderling VB, Schaart G, Mensink RP, Schrauwen P. Three weeks on a high-fat diet increases intrahepatic lipid accumulation and decreases metabolic flexibility in healthy overweight men. J Clin Endocrinol Metab. (2011) 96:E691-5. doi: 10.1210/jc.2010-2243

62. Bjermo H, Iggman D, Kullberg J, Dahlman I, Johansson L, Persson L, et al. Effects of n-6 PUFAs compared with SFAs on liver fat, lipoproteins, and inflammation in abdominal obesity: a randomized controlled trial. Am J Clin Nutr. (2012) 95:1003-12. doi: 10.3945/ajcn.111.030114

63. Iggman D, Rosqvist F, Larsson A, Arnlov J, Beckman L, Rudling M, et al. Role of dietary fats in modulating cardiometabolic risk during moderate weight gain: a randomized double-blind overfeeding trial (LIPOGAIN study). J Am Heart Assoc. (2014) 3:e001095. doi: 10.1161/JAHA.114.0 01095

64. Luukkonen PK, Sädevirta S, Zhou Y, Kayser B, Ali A, Ahonen L, et al. Saturated fat is more metabolically harmful for the human liver than unsaturated fat or simple sugars. Diabetes Care. (2018) 41:17329. doi: $10.2337 / \mathrm{dc} 18-0071$

65. Tricò D, Biancalana E, Solini A. Protein and amino acids in nonalcoholic fatty liver disease. Curr Opin Clin Nutr Metab Care. (2021) 24:96101. doi: 10.1097/MCO.0000000000000706

66. Bortolotti M, Kreis R, Debard C, Cariou B, Faeh D, Chetiveaux M, et al. High protein intake reduces intrahepatocellular lipid deposition in humans. Am J Clin Nutr. (2009) 90:1002-10. doi: 10.3945/ajcn.2008.27296

67. Romeo S, Kozlitina J, Xing C, Pertsemlidis A, Cox D, Pennacchio LA, et al. Genetic variation in PNPLA3 confers susceptibility to nonalcoholic fatty liver disease. Nat Genet. (2008) 40:1461-5. doi: 10.1038/ng.257

68. Kozlitina J, Smagris E, Stender S, Nordestgaard BG, Zhou HH, TybjærgHansen A, et al. Exome-wide association study identifies a TM6SF2 variant that confers susceptibility to nonalcoholic fatty liver disease. Nat Genet. (2014) 46:352-6. doi: 10.1038/ng.2901

69. Buch S, Stickel F, Trépo E, Way M, Herrmann A, Nischalke HD, et al. A genome-wide association study confirms PNPLA3 and identifies TM6SF2 and MBOAT7 as risk loci for alcohol-related cirrhosis. Nat Genet. (2015) 47:1443-8. doi: 10.1038/ng.3417

70. Meroni M, Longo M, Rustichelli A, Dongiovanni P. Nutrition and genetics in NAFLD: the perfect binomium. Int J Mol Sci. (2020) 21:2986. doi: 10.3390/ijms21082986

71. Bakker LE, Sleddering MA, Schoones JW, Meinders AE, Jazet IM. Pathogenesis of type 2 diabetes in South Asians. Eur J Endocrinol. (2013) 169:R99-114. doi: 10.1530/EJE-13-0307

72. Sattar N, Gill JM. Type 2 diabetes in migrant south Asians: mechanisms, mitigation, and management. Lancet Diabetes Endocrinol. (2015) 3:100416. doi: 10.1016/S2213-8587(15)00326-5

73. Petersen KF, Dufour S, Feng J, Befroy D, Dziura J, Dalla Man C, et al. Increased prevalence of insulin resistance and nonalcoholic fatty liver disease in Asian-Indian men. Proc Natl Acad Sci USA. (2006) 103:182737. doi: 10.1073/pnas.0608537103

74. Hakim O, Bello O, Bonadonna RC, Mohandas C, Shojaee-Moradie F, Jackson $\mathrm{N}$, et al. Ethnic differences in intrahepatic lipid and its association with hepatic insulin sensitivity and insulin clearance between men of black and white ethnicity with early type 2 diabetes. Diabetes Obes Metab. (2019) 21:21638. doi: 10.1111/dom. 13771

75. Hakim O, Bello O, Ladwa M, Christodoulou D, Bulut E, Shuaib H, et al. Ethnic differences in hepatic, pancreatic, muscular and visceral fat deposition in healthy men of white European and black west African ethnicity. Diabetes Res Clin Pract. (2019) 156:107866. doi: 10.1016/j.diabres.2019. 107866

76. Haffner SM, D’Agostino R, Saad MF, Rewers M, Mykkanen L, Selby J, et al. Increased insulin resistance and insulin secretion in nondiabetic African-Americans and Hispanics compared with non-Hispanic whites. the insulin resistance atherosclerosis study. Diabetes. (1996) 45:7428. doi: 10.2337/diabetes.45.6.742

77. Sumner AE, Micklesfield LK, Ricks M, Tambay AV, Avila NA, Thomas $\mathrm{F}$, et al. Waist circumference, BMI, and visceral adipose tissue in white women and women of African descent. Obesity. (2011) 19:6714. doi: 10.1038/oby.2010.201

78. Goedecke JH, Chorell E, Livingstone DE, Stimson RH, Hayes P, Adams K, et al. Glucocorticoid receptor gene expression in adipose tissue and associated metabolic risk in black and white South African women. Int J Obes. (2015) 39:303-11. doi: 10.1038/ijo.2014.94

79. Toledo-Corral CM, Alderete TL, Hu HH, Nayak K, Esplana S, Liu $\mathrm{T}$, et al. Ectopic fat deposition in prediabetic overweight and obese minority adolescents. J Clin Endocrinol Metab. (2013) 98:1115-21. doi: 10.1210/jc.2012-3806

80. Thyfault JP, Rector RS. Exercise combats hepatic steatosis: potential mechanisms and clinical implications. Diabetes. (2020) 69:517-24. doi: 10.2337/dbi18-0043

81. Cuthbertson DJ, Shojaee-moradie F, Sprung VS, Jones H, Pugh CJA, Richardson $\mathrm{P}$, et al. Dissociation between exercise-induced reduction in liver fat and changes in hepatic and peripheral glucose homeostasis in obese patients with non-alcoholic fatty liver disease. Clin Sci. (2016) 130:93104. doi: 10.1042/CS20150447

82. Pugh CJ, Sprung VS, Jones H, Richardson P, Shojaee-Moradie F, Umpleby $\mathrm{AM}$, et al. Exercise-induced improvements in liver fat and endothelia function are not sustained 12 months following cessation of exercise supervision in nonalcoholic fatty liver disease. Int J Obes. (2016) 40:192730. doi: 10.1038/ijo.2016.123

83. Walhin JP, Richardson JD, Betts JA, Thompson D. Exercise counteracts the effects of short-term overfeeding and reduced physical activity independent of energy imbalance in healthy young men. J Physiol. (2013) 591:623143. doi: 10.1113/jphysiol.2013.262709

84. Walhin JP, Chen YC, Hengist A, Bilzon J, Betts JA, Thompson D. The effects of different forms of daily exercise on metabolic function following short-term overfeeding and reduced physical activity in healthy young men: study protocol for a randomised controlled trial. Trials. (2018) 19:199. doi: 10.1186/s13063-018-2579-6

Conflict of Interest: The authors declare that the research was conducted in the absence of any commercial or financial relationships that could be construed as a potential conflict of interest.

Copyright (c) 2021 Hydes, Alam and Cuthbertson. This is an open-access article distributed under the terms of the Creative Commons Attribution License (CC BY). The use, distribution or reproduction in other forums is permitted, provided the original author(s) and the copyright owner(s) are credited and that the original publication in this journal is cited, in accordance with accepted academic practice. No use, distribution or reproduction is permitted which does not comply with these terms. 